\title{
Inter-American Development Bank
}

Institutions for Development (IFD)

TECHNICAL NOTE No. IDB-TN-496

\section{Effects of Innovation on Employment in Latin America}

Gustavo Crespi

Ezequiel Tacsir 


\section{Effects of Innovation on Employment in Latin America}

Gustavo Crespi

Ezequiel Tacsir

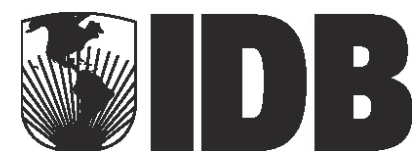

Inter-American Development Bank 2012 
Cataloging-in-Publication data provided by the

Inter-American Development Bank

Felipe Herrera Library

Crespi, Gustavo.

Effects of innovation on employment in Latin America / Gustavo Crespi, Ezequiel Tacsir.

p. cm. - (IDB Technical Note ; 496)

Includes bibliographical references.

1. Unemployment-Effect of technological innovations on-Latin America. 2. Technological innovationsLatin America. 3. Research, Industrial-Latin America. 4. Employment (Economic theory). I. Tacsir,

Ezequiel. II. Inter-American Development Bank. Competitiveness and Innovation Division. III. Title. IV.

Series.

IDB-TN-496

http://www.iadb.org

The opinions expressed in this publication are those of the authors and do not necessarily reflect the views of the Inter-American Development Bank, its Board of Directors, or the countries they represent.

The unauthorized commercial use of Bank documents is prohibited and may be punishable under the Bank's policies and/or applicable laws.

Copyright (C) 2012 Inter-American Development Bank. All rights reserved; may be freely reproduced for any non-commercial purpose.

Gustavo Crespi: gcrespi@iadb.org

Ezequiel Tacsir: ezequielt@iadb.org 


\title{
Effects of Innovation on Employment in Latin America
}

\author{
Gustavo Crespi and Ezequiel Tacsir ${ }^{*}$
}

\begin{abstract}
$^{* *}$
This study examines the impact of process and product innovation on employment growth and composition in Argentina, Chile, Costa Rica, and Uruguay using micro data from innovation surveys. Based on the model put forward by Harrison et al. (1998), employment growth is related to process innovations and to the growth of sales separately due to innovative and unchanged products. Results show that compensation effects are pervasive and that the introduction of new products is associated with employment growth at the firm level. No evidence of displacement effects due to the introduction of product innovations was observed. With respect to the impact of innovation on employment composition, there is scant evidence of a skill bias, although product innovation is more complementary to skilled than to unskilled labor.
\end{abstract}

JEL: O12, O14, O31, O33, O40, J21

Keywords: innovation, employment, developing countries, Latin America, innovation surveys

\footnotetext{
* Competitiveness and Innovation Division, Inter-American Development Bank, 1300 New York Av. NW, Washington, D.C. 20577, USA. Contact details: gcrespi@iadb.org and ezequielt@iadb.org.

** This work is part of the research project entitled "Employment Generation, Firm Size and Innovation in Latin America: the Microeconometric Evidence (RG-K1164)" coordinated by the Competitiveness and Innovation Division of the Inter-American Development Bank. This paper would not have been possible without the motivation and collaboration of the various researchers participating in this project: Diego Aboal (CINVE), Roberto Alvarez (INTELIS), Jose Miguel Benavente (INTELIS), David Giulidori (ECONFOCUS), Bibiana Lanzilotta (CINVE), Ricardo Monge (CAATEC), Jeffrey Orozco (CINPE), and Rodolfo Stucchi (ECONFOCUS). The authors would like to thank Pierre Mohnen, Jacques Mairesse and Marco Vivarelli for their technical assistance and peer review throughout the project.
} 


\section{Introduction}

Innovation is widely considered to be a primary source of economic growth, and policies to encourage firm-level innovation are high on the agenda in most Latin American countries. But innovation alone may not be sufficient to generate employment. Moreover, for countries facing labor market problems, persistent poverty, and inequality, employment generation is probably the main route out of poverty and the most efficient way to reduce inequality. Thus, the effects of innovation on employment are of particular interest.

The relationship between innovation and employment is complex. Innovation could trigger direct (mainly firm-level), partial, and general equilibrium effects on employment, and across all these levels the relationship between these variables depends on many different transmission mechanisms, feedback loops, and institutional factors (Pianta, 2006; Vivarelli, 2011). Recent evidence regarding the firm-level relationship between innovation and employment in developed economies indicates that whether and how innovation creates new jobs depends first and foremost on the type of innovation (Harrison, et al. 2008; Hall et al., 2008; Lachenmaier and Rottmann, 2011) and the sector (Greenhalgh, Longland, and Bosworth, 2001; Coad and Rao, 2011; Bogliacino, Piva, and Vivarelli, 2011).

In addition, the effects of innovation on innovators' employment depend on the state of the technology that determines the extent to which innovation improves productivity and the demand conditions that induce different compensating effects. ${ }^{1}$ At the sector level, innovation can also trigger indirect effects, including the competitive redistribution of outputs and jobs from low to high innovation-intensive firms, job losses due to the exit of non-innovative firms, and job creation from innovative spin-offs. For instance, Greenan and Guellec (2000) find that although innovating firms create more jobs than non-innovating ones, the reverse is true at the sectoral level. Finally, general equilibrium effects clearly emerge when the interactions between different markets are considered. Indeed, how fast innovators can meet increased demand depends in part on how fast complementary inputs produced by other industries can be supplied. Innovation can also affect employment through complementarities in consumption goods and increased variety

\footnotetext{
${ }^{1}$ This applies to both process and product innovation. Although process innovations might displace labor in the short term, in the extent that productivity gains are passed through to prices and consumers react to price reductions, it might increase labor in the long term. The opposite applies to product innovations, in the extent that short-term demand shifts might be compensated by imitators later on.
} 
or better quality of intermediate inputs. Finally, new products could lead to completely new economic activities (Harrison et.al, 2008; Klette and Forre, 1998; Spiezia and Vivarelli, 2002; Doms, Dunne and Roberts, 1995; Pianta, 2006).

The evidence on the relationship between innovation and employment is lacking for Latin America where the very idiosyncratic nature of innovation means that the above mentioned findings cannot be simply extrapolated to this region. ${ }^{2}$ Indeed, for Latin American firms, the acquisition of technological knowledge from abroad through contacts, trade, collaborations, and joint ventures with industrialized countries is very relevant (Katz, 1987). Technological change in developed countries might respond to different objectives, incentives, and factor endowments as well as go in different directions from technological change in developing countries. Innovations borrowed from developed countries may not be fully adaptable to developing country contexts and may produce different effects on employment than locally developed innovations. Thus, it is not only that Latin American firms might produce different types of innovations (based on imitation of the best-practice frontier rather than being the first to introduce world-class innovations) but also that the very nature of the innovation process is different. Consequently, the effects of innovation on employment generation in this region might be quite different.

Furthermore, in Latin America there are important structural features that might lead to different outcomes of innovation on employment. In the first place, the current production structure is strongly dominated by small- and medium-sized enterprises (SMEs). The innovation process is very different in SMEs than in large firms. Indeed, innovation in SMEs is strongly dominated by informal search routines and learning from already available knowledge and technologies, while in large firms, innovation processes are more systematic and tend to be formalized in R\&D labs (Baldwin, 1997). Thus, the typical business innovation strategy observed in Latin America is quite different from that which is dominant in frontier economies. Second, Latin America's production structure is heavily dominated by the manufacturing of commodities and low technologically intensive goods. To the extent that in these sectors the

\footnotetext{
${ }^{2}$ Before the IDB project, there were only two papers on innovation and employment in LAC: Benavente and Lauterbach (2009) on Chile, and Fajnzylber and Fernandes (2004) on Brazil. While the first paper deals only with employment quantity issues in a cross-section setting, the second one only discusses composition effects and uses trade proxies as controls for technology, so it does not properly control for innovation.
} 
dominant innovation strategy is more related to process than product innovations, the expected effects of innovation on employment might be different. ${ }^{3}$

This paper aims at closing the evidence gap on the effects of innovation on employment growth at the firm level in Latin America by using innovation surveys for four Latin American countries: Argentina, Chile, Costa Rica, and Uruguay. Specifically, this paper will highlight the existing relationship between innovation outputs and employment growth and its effects on skill composition, taking into account size and sector differences. Firm-level data enables the innovation process to be accounted for and related to the firm's employment trends. ${ }^{4}$

The rest of this paper is organized as follows. Section 2 presents the relationship between innovation and employment. Special emphasis is placed on explaining potential identification problems and the need to implement instrumental variable (IV) estimation techniques to obtain consistent results. Section 3 describes the sources of the data used and presents the main characteristics of the firms' behavior in the four countries under study. Section 4 presents the results on employment growth and uses these results to decompose the different effects of innovation on employment growth. Section 6 presents the relationship between innovation output and employment composition in terms of skills. Section 7 offers conclusions.

\section{Relationship between Innovation and Employment Generation}

Recent evidence on the firm-level relationship between innovation and employment in developed economies indicates that whether and how innovation creates new jobs depends first and foremost on the type of innovation (Harrison, et al., 2008). ${ }^{5}$ Specifically, the effects of innovation on employment (quantity) depend on the relative intensity of the displacement and compensation effects that it might induce. The introduction of new processes is generally driven by labor cost considerations and tends to reduce labor (i.e., displacement). At the same time, the

\footnotetext{
${ }^{3}$ A companion paper (Crespi and Zuñiga, 2012) presents the results for the relationship between innovation strategies of the firm and employment growth and composition for the same set of countries and with the same disaggregates related to size and sector.

${ }^{4}$ Unfortunately, this approach has some shortcomings. Vivarelli (2011:14) notes that the microeconomic approach cannot fully take into account the indirect compensation effects, while the analysis might present a "positive bias" in which "microeconomic analyses generally show a positive link between technology and employment, since they do not consider the important effect on the rivals, which are crowded out by the innovative firms."

${ }^{5}$ See Vivarelli (2011) for an account of the evidence on the effects of process and product innovation in developed countries.
} 
introduction of new products or services may replace or add to the list of existing products or services with different effects on employment generation (see Figure 1). Organizational innovation is frequently an indispensable complement to the adoption of new technologies critically affecting the productivity and employment consequences of technological innovation, especially ICTs (Black and Lynch, 2004).

Figure 1. Employment Effects of Innovation

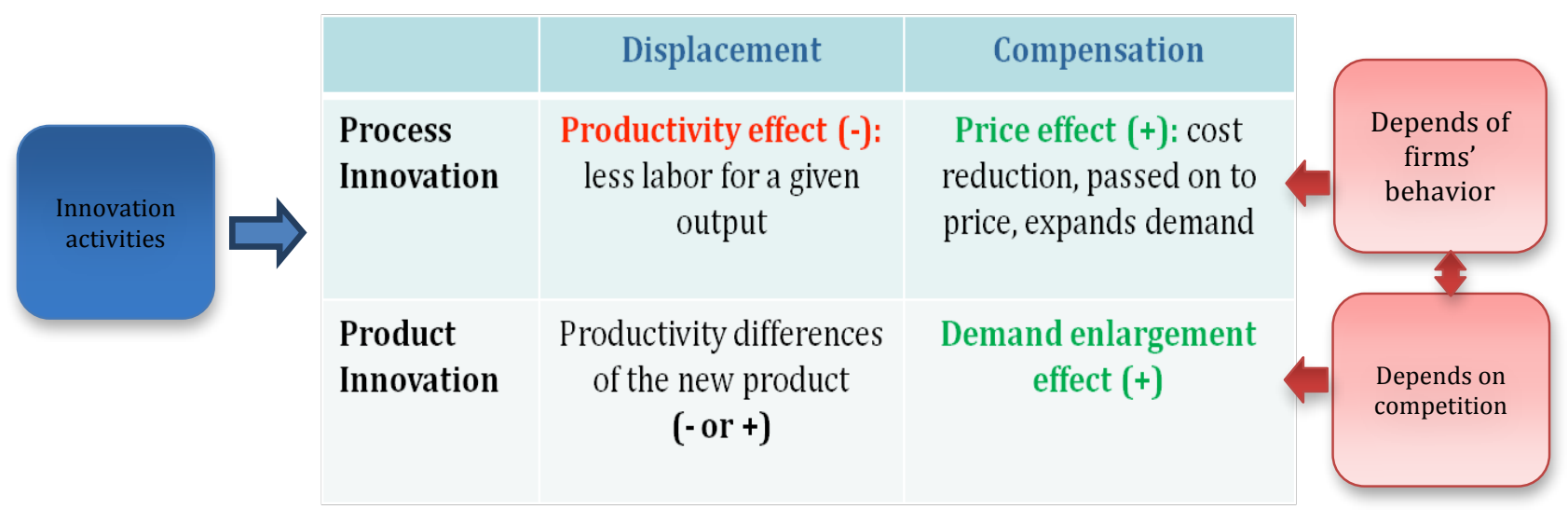

Source: Adapted from Harrison et al. (2008).

Harrison, et al. (2008) show that in order to untangle the employment-creating versus displacing effect of innovation, a distinction between product and process innovation is useful. This research will take the same starting point. In the basic model, two types of products are distinguished: the production of existing products and the production of new products. The change in employment is then decomposed into the part due to the increased efficiency in production of old products (which could be related to process and organizational innovations) and the part due to the introduction of new products (product innovations). Hence, it is possible to capture the relative extent of the expansion and displacement effect of innovation on employment, as follows.

We assume that a firm can produce two types of products: "old products" and "new products." Outputs of old and new products at time $\mathrm{t}$ are denoted $Y_{1 t}$ and $Y_{2 t}$ respectively. We observe firms at two points in time, at the beginning $(\mathrm{t}=1)$ and at the end of the period $(\mathrm{t}=2)$. We also assume that each type of product is produced with an identical separable technology production function, with constant returns to scale in capital and labor. Each production 
technology has an associated efficiency parameter $-\theta_{i t}-$ that change over time. New products can be produced with higher or lower efficiency than old products, and the firm can influence the efficiency of production of either product through investments in process innovation. The firm's cost function at time $\mathrm{t}$ can then be written as follows:

$$
C\left(w_{1 t}, w_{2 t}, Y_{1 t}, Y_{2 t}, \theta_{1 t}, \theta_{2 t}\right)=c\left(w_{1 t}\right) \frac{Y_{i t}}{\theta_{1 t} e^{\eta+\omega_{i t}}}+c\left(w_{2 t}\right) \frac{Y_{2 t}}{\theta_{2 t} e^{\eta+\omega_{2 t}}}(1)
$$

where $c(w)$ is a function of input prices. In the production of each good, we assume that firm productivity levels are affected by unobservable firm-specific fixed effects $(\eta)$ and idiosyncratic shocks $(\omega$ 's). The $\eta$ captures all of the factors that make the firm more productive but remain constant over time (e.g., superior innovation management skills, location, etc.), while the $\omega$ 's captures time varying shocks that affect production (e.g., energy shocks, labor disputes, unexpected organizational problems, etc.). According to the Shephard's Lemma, the conditional demand for labor in the production of each product is:

$$
L_{i t}=c_{L}\left(w_{i t}\right) \frac{Y_{i t}}{\theta_{1 t} e^{\eta+\omega_{i t}}}(2)
$$

where $c_{L}(w)$ is the derivative of $c(w)$ with respect to wages. Under the assumption that $c_{L}(w)$ remains constant over the period and that it is the same for old and new products, ${ }^{6}$ the growth rate of employment at the firm level is given by the growth rate of employment allocated to the production of old products plus the growth rate of the employment allocated to the production of new products. Given that the production of new products at the beginning of the period is nil $\left(Y_{21}=0\right)$, we can approximate the employment growth decomposition as follows:

$$
l=\frac{\Delta L}{L}=-\left(\frac{\theta_{12}-\theta_{11}}{\theta_{11}}\right)+\left(\frac{Y_{12}-Y_{11}}{Y_{11}}\right)+\frac{\theta_{11}}{\theta_{22}} \frac{Y_{22}}{Y_{11}}-\left(\omega_{12}-\omega_{11}\right)_{(3)^{7}}
$$

\footnotetext{
${ }^{6}$ This will be the case if relative prices do not change much over time or across new and old products.

${ }^{7}$ For simplicity, we assume that $\mathrm{w}_{11} \sim \mathrm{w}_{22}$.
} 
This expression says that employment growth is the result of the change in efficiency in the production process for the old products, the rate of change in the production of these products, and the expansion attributable to the new products. The increase in the efficiency of the old products' production process is expected to be larger for firms introducing process innovations related to the old products (firms that introduce process innovations only, according to the surveys). On the other hand, the effect of product innovation on employment growth depends on the difference in efficiency between the production processes for the old and the new products. If the new products are produced more efficiently than the old products, then this ratio is less than one and employment does not grow at the same pace as the growth of output accounted for by new products. Equation (3) suggests the following regression to estimate the effects of innovation on employment:

$$
l=\alpha_{0}+\alpha_{1} d+y_{1}+\beta y_{2}+v_{(4)}
$$

where $l$ is total employment growth, $\mathrm{y}_{1}$ is the real growth in sales of old products, $\mathrm{y}_{2}$ is the real growth in sales of new products (product innovations), and $d$ captures the introduction of process innovations in the production of old products. The error term, $v$, captured the productivity shocks In general, one should expect that while innovations in the production processes of old products tend to displace employment, product innovations tend to create employment (unless new products substitute for old products and the production efficiency of new products is higher than that of the old products). ${ }^{8}$

It is clear from the preceding discussion that the effects of innovation on employment depend on the type of innovation carried out by the firms. Given that the type of innovation can differ considerably across sectors, it is natural to assume that the effect of innovation on employment can also differ by sector. In addition, labor market regulations can have different effects depending on firm size. Large firms can circumvent labor rigidities by outsourcing part of their work, while this is more difficult for small firms. On the other hand, in the Latin American

\footnotetext{
${ }^{8}$ Real growth in sales of old products, $\mathrm{y}_{I}$ is the result of three different effects: the autonomous increase in firm demand for the old products, the compensation effect induced by any price variation following a process innovation, and the demand substitution effect resulting from the introduction of new products. As these components cannot be disentangled without additional data, in practice $\mathrm{y}_{l}$ will be simply subtracted from 1 , so an alternative specification for (4) is to use the inverse labor productivity growth as the dependent variable.
} 
context, small firms are also more informal. Thus, in principle, labor regulations might be less binding on them. This heterogeneity can have relevant policy implications, and it is therefore important to pay attention to it. Henceforth, throughout the paper we explore the heterogeneity of the impact of innovation on employment by size, estimating equation (4) separately for small firms and low- and high-tech sectors. ${ }^{9}$

\subsection{Identification Issues, Causality, and Measurement Errors}

Identification estimation of equation (4) can be affected by two different problems: the potential endogeneity of the innovation variables and the measurement error problem generated by using nominal sales rather than real sales among the regressors. With regard to the endogeneity problem, consistent estimation of equation (4) relies on the lack of correlation between the variables representing process and product innovations and the error term. Innovations are the result of investment decisions ( $R \& D$, for example), which have to be decided by the firms in advance. These decisions depend on firm's productivity, which can be characterized as an unobservable made of two components: firm attributes that are mainly constant over time (such as managerial skills or the $\eta$ 's in our previous notation) and productivity shocks (the $\omega$ 's). Hence, if innovation investments are correlated with firm productivity, innovation outputs will be as well. This will lead, in turn, to innovation outputs being endogenous, creating a serious problem of identification.

Given that equation (4) is specified as a real growth rate, it is expected that the influence of firm-specific fixed effects is already removed from the error term. The correlation between innovation outputs and productivity shocks (they remain in the error term of equation [4]) depends on the exact timing of investment decisions. If investment decisions are made in advance of productivity shocks (for example because there is a "time-to-build" period between when investments decisions are made and actual innovations materialize), innovation variables in (4) will not be correlated with the error term, and equation (4) could be estimated by OLS

\footnotetext{
${ }^{9}$ Unfortunately, the sample size for the innovation survey in Costa Rica does not permit the exercise to be performed for high- and low-technology sectors. This analysis is presented only for the three other countries.
} 
methods. ${ }^{10}$ If, on the other hand, investment decisions are made at the same time as productivity shocks are observed, innovation outputs might become endogenous in equation (4).

In this case, it is worth exploring the potential direction of this bias. If process innovation $(d)$ is positively correlated with the productivity shock of old products in the second period $\left(\omega_{12}\right)$, the fact that this shock enters the error term in (4) preceded by a negative sign means that the correlation between process innovation and the error term will be actually negative. So, OLS results will tend to overestimate any displacement effect or to underestimate any compensating effect of process innovation. On the other hand, for product innovation, we expect a negative correlation between this variable and the error term as well because while $\left(\omega_{11}\right)$ shows up in the error term with a positive sign, $\left(\mathrm{Y}_{11}\right)$ shows up in the denominator of this equation. That means that estimating equation (4) using OLS will underestimate the true impact of product innovation on employment growth. In summary, the OLS-estimated impacts of innovation on employment growth should be interpreted as the "lower bounds" of the true relationship among these two variables.

The identification of the true relationship will depend on the availability of instruments correlated with the innovation variables and uncorrelated with the error term. Although the innovation surveys provide interesting information that can be used as instruments, the majority of them are actually more suitable for the identification of product than process innovation, which is a relatively more idiosyncratic outcome. It is important to consider that the majority of the firms in the sample that report having introduced a product innovation have done so in combination with a process innovation (a phenomenon known as "co-innovation" in the literature). In the empirical implementation, these firms will be considered product innovators. The proportion of firms introducing process innovation only is fairly small, so even when the results for this variable are downward biased, the actual impact of this problem on employment growth is expected to be of second order. Thus, in the empirical implementation, the focus will be on getting reliable estimates for product innovation, maintaining the assumption that processonly innovation is fairly exogenous. ${ }^{11}$

\footnotetext{
${ }_{10}$ This is the sort of timing for investment decisions underlying Olley and Pakes (1996).

${ }^{11}$ There are good reasons to think that process innovation can in fact be exogenous. As Harrison et al. (2008) noted, it seems realistic to assume that firms cannot predict future labor problems, supply chain disruptions, or organization shocks when deciding their process innovation investments. Accordingly, the hypothesis on exogeneity of process innovations is maintained in this paper. However, we carry out some robustness checks to review whether this assumption is attainable.
} 
A second possible source of endogeneity is the presence of measurement error. Ideally, in equation (4) we would like to have the real production growth of old (y1) and new products (y2). Instead, we must replace these two variables with nominal sales growth rates ( $g 1$ and $g 2$ ) because we do not have firm-level prices. For both products, nominal sales growth rates can be approximately decomposed into two terms: real growth rates and price changes. In other words, we have: $\mathrm{g}_{1}=\mathrm{y}_{1}+\pi_{1}$ for old products and $\mathrm{g}_{2}=\mathrm{y}_{2}+\pi_{2}$ for new products. Substituting these two expressions in (4) and moving the nominal sales growth rates of old products to the left hand side, we have:

$$
l-g_{1}=\alpha_{0}+\alpha_{1} d+\beta g_{2}+\left(-\pi_{1}-\beta \pi_{2}+v\right)_{(5)}
$$

Hence, the growth in prices of old and new products is left in the error term, and correlation between growth in prices of new products $\pi_{2}$ and $g_{2}$ can create an additional bias for product innovation. As before, this will also be an attenuation bias in the estimation of $\beta$ when estimated using the OLS method. To deal with this measurement error problem, we follow Harrison et al. (2008) and we use instrumental variables that are correlated with real growth in the production of new products, but uncorrelated with its nominal growth.

According to Harrison et al. (2008), the use of nominal sales growth rates will also affect the interpretation of the results for process innovation. The price growth rates of old products can itself be affected by the efficiency impact of process innovation, to the extent that these efficiency gains are expressed in the prices. In order words, it is possible that $\pi_{1}=\pi_{0}+\gamma \alpha_{1} \mathrm{~d}$, where $\gamma$ is a pass-through parameter that exists in the interval $[0,1]$. So, by replacing this in equation 5 we get:

$$
l-g_{1}=\alpha_{0}+(1-\gamma) \alpha_{1} d+\beta g_{2}+\left(-\pi_{0}-\beta \pi_{2}+v\right)_{(5.1)}
$$

In the absence of firm-level data, true displacement effect of process innovation might also be underestimated. The severity of this problem will depend on the size of the pass-through effects. If these effects are large, with $\gamma \sim 1$, we might end up getting a non-significant effect of process innovation on employment growth. In order to partially correct for this problem, we 
follow the strategy developed by Harrison et al. (2008), which consists of approximating firmlevel prices $(\pi 1)$ by using industry-level deflators $(\pi)$. Thus, the estimate is:

$$
l-\left(g_{1}-\pi\right)=\alpha_{0}+\alpha_{1} d+\beta g_{2}+\left(-\left(\pi_{1}-\pi\right)-\beta \pi_{2}+v\right)_{(6)}
$$

If firm level prices do not deviate much from industry-level deflators $\left(\pi \sim \pi_{1}\right)$, we might be able to obtain more consistent estimations of the displacement effect of process innovation of employment.

\subsection{Innovation and Employment Quality}

Depending on the skill bias of innovation, its impact may be different for skilled and unskilled workers. If innovation is skilled-biased, as several empirical and theoretical studies argue (see, for example, Card and Dinardo, 2002; Acemoglu, 1998), higher innovation could be associated with lower employment growth for unskilled workers and higher employment growth for skilled workers.

To analyze the effect of innovation on employment composition, we follow the earlier approach and use a variation of equation (6) for assessing the innovation impact on employment quality. Specifically, we split the growth rate of employment in both skilled $\left(l_{s}\right)$ and unskilled workers $\left(l_{u s}\right)$.

$$
\begin{gathered}
l_{i t}^{s}-\left(g_{1 i t}-\pi\right)=\alpha_{0}^{s}+\alpha_{1}^{s} d_{i t}+\beta^{s} g_{2 i t}+\varepsilon_{i t}(7) \\
l_{i t}^{u s}-\left(g_{1 i t}-\pi\right)=\alpha_{0}^{u s}+\alpha_{1}^{u s} d_{i t}+\beta^{u s} g_{2 i t}+\eta_{i t}(8)
\end{gathered}
$$

The dependent variable is employment growth (minus old product real sales growth) for both types of workers: skilled and unskilled. In doing so, $l_{s}$ can be estimated as the rate of growth of the sum of employees with technical and professional education, while lus is the rate of growth of the sum of employees with only basic education or less. In short, through equations (7) and (8) we can assess the extent to which innovation, both in process and product separately, affect employment generation when we consider employment quality and not only total employment. Once again, we will use instrumental variables as discussed before in order to address the identification problem related to correlation between $d$ and $g 2$ and the error term. 


\section{Data Sources}

The models just described are run for four Latin American countries with a focus on the manufacturing industry. Innovation surveys used were: Argentina (1998-2001), Chile (1995, 1998, 2001, 2005 and 2007), Costa Rica (2006-2007), and Uruguay (1998-2000, 2001-2003, 2004-2006 and 2007-2009). The findings presented here are the results of a collaborative project in which a team of researchers from each of these countries implemented a common empirical model. A series of national studies have been conducted in parallel by local researchers to fully exploit the richness of each individual survey. ${ }^{12}$

Specifically, in the case of Argentina, we use data from Second National Innovation Survey (1998-2001) conducted in 2003 by the National Institute of Statistics and Census (INDEC) and gathering retrospective information for each year between 1998 and 2001. The firms surveyed are the same firms surveyed in the Annual Industrial Survey: manufacturing firms with 10 or more employees. With a response rate of 76 percent (questionnaires were distributed to 2,229 firms, of which 1,688 responded), the sampling frame includes 23 industries. Twenty-two of them are industries classified according to two digits of ISIC-Rev3, and the remaining one includes firms with linkages to the Ministry of Defense or the National Commission of Atomic Energy.

In the Chilean case, there are several waves of the innovation survey available for studying the issue in question. We use the innovations surveys carried out in 1995, 1998, 2001, 2005, and 2007. This information is complemented by firm-specific information obtained from the Annual Survey of Manufactures (ENIA). This link between the two sources of information is relevant given that innovation surveys tend to have limited information on firm characteristics.

For Costa Rica, the main source of data used in the study is the Costa Rican Innovation Survey for the years 2006-2007. This survey is based on a statistically representative sample of the manufacturing, energy, and telecommunications sectors. According to the official data of the National Institute of Statistics and Census (INEC), these sectors comprised a total of 2,285 firms. In the case of the 2006-2007 survey, the INEC provided a sample of 566 firms distributed over all sectors. Using this sample, it was possible to obtain complete responses from 376 firms. After

\footnotetext{
${ }^{12}$ See Aboal et al. (2011), Alvarez et al. (2011), De Elejalde et al. (2011), and Monge et al. (2011).
} 
eliminating firms from energy and telecommunications and any manufacturing firms with fewer than 10 employees, we ended up with a sample of 208 firms.

Finally, of the data on Uruguay was derived from four waves of Manufacturing Innovation Surveys: 1998-2000, 2001-2003, 2004-2006 and 2007-2009, as well as the annual Economic Activity Surveys (EAS) for the period 1998-2007. The innovation survey data are collected by the National Bureau of Statistics (INE) in parallel with the EAS (same sample and statistical framework). In the case of the innovation survey, all firms with more than 49 workers are included. Units with 20 to 49 employees and with fewer than 19 workers are selected using simple random sampling within each economic sector at the ISIC 2-digit level up to 2005. Since then, random strata are defined as those units with fewer than 50 workers within each economic sector at the ISIC 4-digit level.

When comparing results across countries, we need to bear in mind that business, economic, and policy environments in Latin America differ between countries and generally diverge from OECD countries; thus, in principle, the results are not expected to be similar to those reported in previous studies. Finally, as this is an analysis of the manufacturing industry, which represents a small share of the total economy in some countries (IDB, 2010; Tacsir, 2011), the results apply only to this industry. We acknowledge, however, that innovation is relatively more important in manufacturing than in service industries (Crespi and Zuñiga, 2010).

\subsection{Descriptive Statistics}

Innovation surveys contain detailed information on the firms' characteristics, innovation activity, and employment - both the number of employees and employment composition by education and length of the labor contracts. Importantly, they contain detailed information on the composition of sales, which allows us to compute the percentage of sales corresponding to new products and from this the nominal growth rate of new products $\left(\mathrm{g}_{2}\right){ }^{13}$

Firms were classified in mutually exclusive categories according to their innovation status: product innovators, process only innovators, and non-innovators. Product innovators are

\footnotetext{
${ }^{13}$ Actually, all of the surveys have a question asking for the share a sales at the end of the period that are the result of product innovations introduced over the last two or three years, depending on the survey. We call this share s. The surveys also include information on the nominal growth rates of total sales ( $\mathrm{g}$ ). Thus, it can be shown that given that the sales of new products at the beginning of the period is zero by definition, the nominal growth rates of new products can be obtained as $\mathrm{g}_{2}=\mathrm{s}(1+\mathrm{g})$.
} 
firms that have introduced product innovations. Process-only innovators are firms that have introduced process innovations or organizational change innovations excluding product innovators. Non-innovators are firms not classified as product or process innovators. Following Harrison et al. (2008), we classify firms that have introduced both product and process innovations as product innovators. The implicit assumption is that product and process innovators are more similar to product innovators than to process-only innovators.

Table 1 presents the share of innovative firms, employment growth, sales growth, and labor productivity in the four countries under study. Table 1 shows the high proportion of innovative firms in the region. In fact, the proportion of innovative firms ranges from 51.9 percent (in Uruguay) to 78 percent (in Costa Rica). Among them, more than half of the innovators have introduced product innovations.

Despite the difference in overall performance across countries, it is evident that, with the exception of Chile, innovators perform better than non-innovators in terms of employment creation. Although less clear, a similar situation arises in the case of sales. Innovators exhibit better sales performance with the exception of Costa Rica, where process innovators show smaller growth rates than non-innovators (partially due to a small growth rate in prices).

Similarly, Table 2 offers descriptive statistics for small manufacturing firms. Here, a SME is defined in the four countries as those firms with less than 50 employees. We observe that this group of firms, although still presents a high percentage of firms with innovation outputs, the share is lower than for in the case of the full sample. Here, with the sole exception of Costa Rica, all countries present shares slightly below 50 percent.

Again, employment growth is higher for the innovators than for the non-innovators. Only in Argentina, the employment growth of those firms that are product innovators is below that of the non-innovators counterparts. In relation to employment growth, data for Argentina, Chile, and Uruguay clearly show higher rates of growth in innovating firms. 
Table 1. Manufacturing Firms: Process and Product Innovators, Growth of Employment and Sales

\begin{tabular}{|c|c|c|c|c|}
\hline Manufacturing firms & Argentina & Chile & Costa Rica & Uruguay \\
\hline Number of observations & 1,415 & 2,049 & 208 & 2,532 \\
\hline \multicolumn{5}{|l|}{ Distribution of firms (\%) } \\
\hline Non-innovators (no process or product innovations) & 37.0 & 42.6 & 22.0 & 48.1 \\
\hline Process only innovators (non-product innovators) & 15.0 & 4.0 & 4.0 & 19.4 \\
\hline Product innovators & 48.0 & 53.4 & 74.0 & 32.5 \\
\hline Number of employees at the beginning of (each) survey & 233.0 & 214.5 & 182.0 & 91.2 \\
\hline Foreign ownership ( $10 \%$ or more) $(\%)$ & 20.0 & 12.5 & 14.9 & 13.2 \\
\hline Located in the capital of the country (\%) & 64.0 & 52.0 & 57.7 & 81.0 \\
\hline \multicolumn{5}{|l|}{ Employment growth (\%) (yearly rate) } \\
\hline All firms & -4.0 & -0.2 & 3.3 & -0.7 \\
\hline Non-innovators (no process or product innovations) & -6.0 & 0.8 & 3.5 & -3.4 \\
\hline Process only innovators (non-product innovators) & -3.9 & 2.1 & 7.4 & 1.7 \\
\hline Product innovators & -2.5 & -0.5 & 3.0 & 1.8 \\
\hline \multicolumn{5}{|l|}{ Sales growth (\%) (nominal growth) (yearly rate) (a) } \\
\hline All firms & -9.0 & 6.5 & 23.7 & 5.5 \\
\hline Non-innovators (no process or product innovations) & -12.5 & 2.9 & 27.3 & 1.7 \\
\hline Process only innovators (non-product innovators) & -8.1 & 7.1 & 11.7 & 9.6 \\
\hline Product innovators & -6.7 & 8.5 & 23.7 & 8.7 \\
\hline \multicolumn{5}{|l|}{ of which: } \\
\hline Old products & -45.3 & -5.7 & -54.9 & -21.2 \\
\hline New products & 38.7 & 14.2 & 78.6 & 29.9 \\
\hline \multicolumn{5}{|l|}{ Labor productivity growth $(\%)^{(a)}$ (yearly rate) } \\
\hline All firms & -5.0 & 6.7 & 20.5 & 6.2 \\
\hline Non-innovators (no process or product innovations) & -6.5 & 2.1 & 23.8 & 5.1 \\
\hline Process only innovators (non-product innovators) & -4.3 & 4.9 & 4.3 & 7.9 \\
\hline Product innovators & -4.2 & 9.0 & 20.4 & 6.9 \\
\hline \multicolumn{5}{|l|}{ Prices growth (\%) ${ }^{(\mathrm{b})}$} \\
\hline All firms & -2.0 & 5.0 & 14.3 & 6.8 \\
\hline Non-innovators (no process or product innovations) & -2.3 & 3.8 & 14.1 & 6.8 \\
\hline Process only innovators (non-product innovators) & -1.9 & 5.0 & 11.8 & 6.8 \\
\hline Product innovators & -1.9 & 5.6 & 14.6 & 6.8 \\
\hline
\end{tabular}

Source: Authors' elaboration based on country studies.

Notes: Argentina (AR)-Innovation Survey 1998-2001; Chile (CH): pooled regressions for the innovation surveys 1995, 1998, 2001, 2007; Costa Rica (CR): Innovation survey 2006-2007 Uruguay: pooled regressions for the surveys 1998-2000, 2001-2003, 2004-2006 and 2007-2009. Notes: Product innovators are firms that have introduced product innovations. Process only innovators are firms that have introduced process innovations or organizational change innovations excluding product innovators. Non-innovators are firms not classified as product or process innovators. Sample: Firms with information in all the relevant variables for the empirical analysis. (a) Sales growth for each type of firm is the average of the variable $g$ and averages for old and new products are the averages of variables $g 1$ and g2, respectively, and (b) prices computed for a set of industries and assigned to firms according to their activity. 
Finally, we also studied the presence of heterogeneous effects in industries with different levels of technology intensity. Industries were classified as low-tech or high-tech based on their innovation expenditure-to-sales ratio. Industries with ratios below the median are considered low-tech industries, and industries (considered at the 2-digit level of ISIC) with ratios above the median are considered high-tech industries (see Table A.1 in Appendix 1 this description for Argentina, Chile and Uruguay). This description shows that for both Chile and Uruguay, firms classified as high tech present a bigger share of innovators (both process and product) among their ranks. With the exception of product innovators in Chile, and similar to the previous evidence, innovators exhibit higher rates of employment growth than non-innovators. In respect to sales, data shows that the growth rates for innovator firms are higher than in those without innovations for every country and technological intensity. 


\section{Table 2. Small Manufacturing Firms: Process and Product Innovators, Growth of Employment and Sales}

\begin{tabular}{|c|c|c|c|c|}
\hline S mall manufacturing firms & Argentina & Chile & Costa Rica & Uruguay \\
\hline Number of observations & 417 & 652 & 119 & 1,353 \\
\hline \multicolumn{5}{|l|}{ Distribution of firms (\%) } \\
\hline Process only innovators (non-product innovators) & 12.0 & 3.7 & 5.9 & 14.0 \\
\hline Product innovators & 32.0 & 28.8 & 64.7 & 23.7 \\
\hline Foreign ownership ( $10 \%$ or more $)$ & 6.0 & 5.8 & 6.7 & 6.2 \\
\hline Located in the capital of the country & 64.0 & 48.2 & 63.9 & 76.7 \\
\hline \multicolumn{5}{|l|}{ Employment growth (\%) (yearly rate) } \\
\hline All firms & -3.5 & 1.4 & 3.6 & -3.7 \\
\hline \multicolumn{5}{|l|}{ Sales growth (\%) (nominal growth) (a) (yearly rate) } \\
\hline All firms & -9.7 & 5.3 & 20.0 & 3.6 \\
\hline Non-innovators (no process or product innovations) & -12.8 & 3.1 & 23.1 & 1.2 \\
\hline Process only innovators (non-product innovators) & -3.0 & 7.6 & 12.8 & 9.4 \\
\hline Product innovators & -6.6 & 8.5 & 19.3 & 6.4 \\
\hline \multicolumn{5}{|l|}{ of which: } \\
\hline Old products & -49.2 & -5.7 & -46.1 & -25.1 \\
\hline New products & 42.6 & 14.2 & 66.1 & 31.5 \\
\hline \multicolumn{5}{|l|}{ Labor productivity growth $(\%){ }^{(a)}$ (yearly rate) } \\
\hline All firms & -2.0 & 3.6 & 13.5 & 7.7 \\
\hline Non-innovators (no process or product innovations) & -2.2 & 1.6 & 14.1 & 7.4 \\
\hline Process only innovators (non-product innovators) & -1.4 & 3.3 & 9.7 & 9.0 \\
\hline Product innovators & -1.9 & 6.4 & 13.6 & 7.7 \\
\hline \multicolumn{5}{|l|}{ Source: Authors' elaboration based on country studies. } \\
\hline \multicolumn{5}{|c|}{$\begin{array}{l}\text { Notes: Argentina (AR)-Innovation Survey 1998-2001; Chile (CH): pooled regressions for the innovation surveys 1995, 1998, 2001, 2007; Costa } \\
\text { Rica (CR): Innovation survey 2006-2007 Uruguay: pooled regressions for the surveys 1998-2000, 2001-2003, 2004-2006 and 2007-2009. } \\
\text { Notes: Product innovators are firms that have introduced product innovations. Process only innovators are firms that have introduced process } \\
\text { innovations or organizational change innovations excluding product innovators. Non-innovators are firms not classified as product or process } \\
\text { innovators. Sample: Firms with information in all the relevant variables for the empirical analysis. (a) Sales growth for each type of firm is the } \\
\text { average of the variable } g \text { and averages for old and new products are the averages of variables g1 and g2, respectively, and (b) prices computed } \\
\text { for a set of industries and assigned to firms according to their activity. }\end{array}$} \\
\hline
\end{tabular}


In summary, the results in Table 1 suggest that employment growth by innovators is higher than by non-innovators. We also find that these results are remarkably stable across firms of different sizes and belonging to sectors with different degrees of technological intensity. The results for product and process innovation are remarkably similar, and there is no strong a priori preliminary evidence that process innovation is particularly harmful for employment growth. Thus, it seems that compensating effects for process innovations are prevalent in the model. In the case of product innovation, we observe that the sales growth rates of old products in the case of product innovators are always negative but more than compensated for by the growth in sales of new products. In the following sections, we explore further the relative impacts of process and product innovations by estimating several variants of the model outlined in the previous section.

\section{Econometric Results of Innovation on Employment}

In this section, we present several results of the effects of innovation on employment growth at the firm level. We begin by presenting the results of OLS-descriptive basic results, and then present those corresponding with equation (6). The section closes with a decomposition exercise as in Harrison et al. (2008). Overall, we analyze the extent to which these effects are different for all manufacturing firms, small firms, and low- and high-tech industries.

\subsection{Naïve Results}

Following Harrison et al. (2008), we first conduct OLS descriptive or "naive" regressions for manufacturing for the total sample, small firms, and the high- and low-tech sectors in each country. These exercises are presented in Tables 3, 4, A.2, and A.3, respectively. In each case, employment growth is regressed on deflated total sales growth, dummies for "process innovation only" and product innovation, and a full set of industry dummies.

These results are partial correlations that can be used to describe the dataset, but they cannot identify the effect of innovation on employment. Table 3 presents this exercise for the whole sample of manufacturing firms. Here, we observe that the coefficient on real sales growth is fairly stable across countries and is a long way below unity in all cases. At face value, this suggests that sales growth is associated with less than one-for-one growth in employment. At the same time, being an innovator (widely defined as product or process innovator) is positively 
related with employment growth except in Costa Rica. When in the case of all manufacturing firms we differentiate the effects of the two types of innovations, we observe that in all cases except Costa Rica, product innovation is positively associated with employment growth. In both Argentina and Uruguay, process innovation also has the same positive effects. Only in the case of Chile does the evidence reveal a negative effect of process innovation on employment growth. No evidence is found on the relationship between process innovation and employment in Costa Rica.

Similar results for the effect of innovation and product and process innovations are found for the sample of small firms (see Table 4) and for analysis differentiation according to innovation intensity at the sectoral level (Tables A.2 and A.3 of Appendix 1). Specifically, and with the exception of Chile, being an innovator is positively related with employment growth in both low- and high-tech sectors. Chile is the only case in which no significant and positive effect was found between product innovation and employment in any sector. With respect to the effect of process innovation, the Uruguayan case exhibits a positive coefficient for both low- and hightech samples, while in Argentina this is only true in the latter case. 
Table 3. Naïve Results for the Whole Sample

\section{Dependent variable: I (Employment growth-yearly)-OLS Estimation}

\begin{tabular}{|c|c|c|c|c|c|c|c|c|}
\hline \multirow{2}{*}{$\begin{array}{l}\text { Sector: manufacturing firms } \\
\text { Regression }\end{array}$} & \multicolumn{2}{|c|}{ Argentina } & \multicolumn{2}{|c|}{ Chile } & \multicolumn{2}{|c|}{ Costa Rica } & \multicolumn{2}{|c|}{ Uruguay } \\
\hline & 1-OLS & 2-OLS & 1-OLS & 2-OLS & 1-OLS & 2-OLS & 1-OLS & 2-OLS \\
\hline Constant & $\begin{array}{c}-5.634 * * * \\
(0.72)\end{array}$ & $\begin{array}{c}-5.490 * * * \\
(0.715)\end{array}$ & $\begin{array}{c}2.109 * * * \\
(0.642)\end{array}$ & $\begin{array}{c}2.621 * * * \\
(0.65)\end{array}$ & $\begin{array}{c}2.339 \\
(3.291)\end{array}$ & $\begin{array}{c}3.606 \\
(2.335)\end{array}$ & $\begin{array}{c}-2.530 * * * \\
(0.38)\end{array}$ & $\begin{array}{c}-2.641 * * * \\
(0.40)\end{array}$ \\
\hline Product or process innovator & $\begin{array}{c}4.088^{* * *} \\
(0.806)\end{array}$ & & $\begin{array}{c}3.144 * * * \\
(0.765)\end{array}$ & & $\begin{array}{c}1.577 \\
(3.443)\end{array}$ & & $\begin{array}{c}7.242 * * * \\
(0.61)\end{array}$ & \\
\hline Product innovator & & $\begin{array}{c}4.862 * * * \\
(0.88)\end{array}$ & & $\begin{array}{c}3.664 * * * \\
(0.829)\end{array}$ & & $\begin{array}{l}-2.730 \\
(3.949)\end{array}$ & & $\begin{array}{c}9.931 * * * \\
(0.71)\end{array}$ \\
\hline $\begin{array}{l}\text { Process only innovator (non- } \\
\text { product innovator) }\end{array}$ & & $\begin{array}{l}2.311^{*} \\
(1.013)\end{array}$ & & $\begin{array}{l}-0.426 \\
(1.078)\end{array}$ & & $\begin{array}{r}3.386 \\
(4.244)\end{array}$ & & $\begin{array}{c}3.286^{* * *} \\
(0.71)\end{array}$ \\
\hline Real sales growth $(g l-\Pi)$ & $\begin{array}{l}0.034 * * \\
(0.011)\end{array}$ & $\begin{array}{c}0.040 * * * \\
(0.012)\end{array}$ & $\begin{array}{c}0.181 * * * \\
(0.021)\end{array}$ & $\begin{array}{c}0.181 * * * \\
(0.021)\end{array}$ & $\begin{array}{c}0.011 \\
(0.016)\end{array}$ & $\begin{array}{l}-0.015 \\
(0.022)\end{array}$ & $\begin{array}{c}0.146^{* * *} \\
(0.02)\end{array}$ & $\begin{array}{c}0.183 * * * \\
(0.02)\end{array}$ \\
\hline 2-digit industry dummies & Yes & Yes & Yes & Yes & Yes & Yes & Yes & Yes \\
\hline Time dummies & No & No & Yes & Yes & No & No & Yes & Yes \\
\hline R-squared & 0.069 & 0.073 & 0.1 & 0.104 & 0.27 & 0.27 & 0.231 & 0.247 \\
\hline Number of firms & 1,415 & 1,415 & 2,049 & 2,049 & 208 & 208 & 2,532 & 2,532 \\
\hline
\end{tabular}

Source: Authors' elaboration based on country studies.

Notes: Product innovators are firms that have introduced product innovations. Process innovators are firms that have introduced process innovations or organizational change innovations. Product only innovators are firms that are product innovators but not process innovators. Process only innovators are firms that are process innovators but not product innovators. Product or process innovators are firms that are product innovators or process innovators. Product and process innovators are firms that are both product innovators and process innovators.

Robust standard errors in parentheses.Significance level: *** 1\%, ** 5\%, and * 10\%. In the cases of both Argentina and Costa Rica it includes as additional control foreign ownsership and a dummy that captures whether the firm is located or not in the capital region. 


\section{Table 4. Naïve Results for Small Firms}

Dependent variable: I (Employment growth-yearly)-OLS Estimation, Small firms

\begin{tabular}{|c|c|c|c|c|c|c|c|c|}
\hline \multirow{2}{*}{$\begin{array}{l}\text { Sector: S mall manufacturing firms } \\
\text { Regression }\end{array}$} & \multicolumn{2}{|c|}{ Argentina } & \multicolumn{2}{|c|}{ Chile } & \multicolumn{2}{|c|}{ Costa Rica } & \multicolumn{2}{|c|}{ Uruguay } \\
\hline & 1-OLS & 2-OLS & 1-OLS & 2-OLS & 1-OLS & 2-OLS & 1-OLS & 2-OLS \\
\hline Constant & $\begin{array}{c}-5.399 * * * \\
(1.292)\end{array}$ & $\begin{array}{c}-5.414 * * * \\
(1.279)\end{array}$ & $\begin{array}{c}2.527^{*} \\
(0.958)\end{array}$ & $\begin{array}{l}2.788^{*} \\
(0.943)\end{array}$ & $\begin{array}{c}1.292 \\
(4.540)\end{array}$ & $\begin{array}{c}3.284 \\
(3.508)\end{array}$ & $\begin{array}{c}-4.434 * * * \\
(0.53)\end{array}$ & $\begin{array}{c}-4.617 * * * \\
(0.55)\end{array}$ \\
\hline Product or process innovator & $\begin{array}{c}5.790 * * \\
(1.768)\end{array}$ & & $\begin{array}{l}4.268^{*} \\
(1.242)\end{array}$ & & $\begin{array}{c}1.582 \\
(4.340)\end{array}$ & & $\begin{array}{c}7.491^{* * *} \\
(0.94)\end{array}$ & \\
\hline Product innovator & & $\begin{array}{l}5.638 * * \\
(2.086)\end{array}$ & & $\begin{array}{l}4.206^{*} \\
(1.417)\end{array}$ & & $\begin{array}{l}-5.837 \\
(6.185)\end{array}$ & & $\begin{array}{c}11.259^{* * *} \\
(1.13)\end{array}$ \\
\hline Process only innovator (non-product innovator) & & $\begin{array}{l}6.114^{* *} \\
(2.028)\end{array}$ & & $\begin{array}{c}0.367 \\
(2.113)\end{array}$ & & $\begin{array}{l}-0.026 \\
(4.556)\end{array}$ & & $\begin{array}{c}2.764 * * * \\
(1.10)\end{array}$ \\
\hline Real sales growth $(g-\Pi)$ & $\begin{array}{c}0.024 \\
(0.025)\end{array}$ & $\begin{array}{c}0.023 \\
(0.026)\end{array}$ & $\begin{array}{c}0.201 * \\
(.035)\end{array}$ & $\begin{array}{c}0.203 * \\
(.036)\end{array}$ & $\begin{array}{c}0.000 \\
(0.024)\end{array}$ & $\begin{array}{l}-0.048 \\
(0.041)\end{array}$ & $\begin{array}{c}0.178^{* * *} \\
(0.02)\end{array}$ & \\
\hline 2-digit industry dummies & Yes & Yes & Yes & Yes & Yes & Yes & Yes & Yes \\
\hline Time dummies & No & No & Yes & Yes & No & No & Yes & Yes \\
\hline R-squared & 0.111 & 0.111 & 0.118 & 0.115 & 0.223 & 0.221 & 0.219 & 0.242 \\
\hline Number of firms & 417 & 417 & 652 & 652 & 119 & 119 & 1,353 & 1,353 \\
\hline
\end{tabular}

\subsection{Innovation and Employment Growth Estimates}

Columns (1) to (4) in Table 5 show the OLS results for the innovation-employment model as outlined in equation (6) for the case of all manufacturing firms. The panel to the right in the same table exhibits the results for the same model for the case of small manufacturing firms. For each country and sample, Table 5 shows the results after controlling for additional variables to those presented in equation (6), namely foreign ownership and whether the firm is located in the capital region of the country.

The OLS results of the innovation-employment model show consistently that product innovation has a positive and significant effect on employment. The estimated coefficient on $g 2$ is close to 1 , which indicates no important differences in efficiency in the production of old and new products. In contrast, Table 5 shows that process innovation either does not have a significant effect on employment or it has a negative one. The negative effect is only found in Chile and Uruguay for the whole sample, and in the latter country when analyzing small firms. 
Table 5. Employment Growth - All Manufacturing and Small Manufacturing Firms Dependent variable: l-(g1-П) - OLS estimation

\begin{tabular}{|c|c|c|c|c|c|c|c|c|}
\hline \multirow{2}{*}{$\begin{array}{l}\text { Sector } \\
\text { Regression }\end{array}$} & \multicolumn{4}{|c|}{ All firms in manufacturing } & \multicolumn{4}{|c|}{ Manufacturing small firms } \\
\hline & AR-OLS & CH-OLS & CR-OLS & UY-OLS & AR-OLS & CH-OLS & CR-OLS & UY-OLS \\
\hline \multirow[t]{2}{*}{ Constant } & $4.139 * * *$ & $1.997 * *$ & -1.616 & $2.662 * * *$ & 2.739 & $3.136^{* *}$ & -0.845 & $1.757 * *$ \\
\hline & $(0.836)$ & $(0.825)$ & $(5.241)$ & $(0.555)$ & $(1.685)$ & $(1.326)$ & $(6.650)$ & $(0.775)$ \\
\hline \multirow[t]{2}{*}{ Process only innovator $(d)$} & -0.601 & $-2.780 * *$ & 8.175 & $-4.002 * * *$ & -2.489 & -3.346 & 5.726 & $-4.127 * *$ \\
\hline & $(1.004)$ & -1.275 & $(6.539)$ & $(1.06)$ & $(2.425)$ & $(2.717)$ & $(8.770)$ & $(1.686)$ \\
\hline \multirow{2}{*}{$\begin{array}{l}\text { Sales growth due to new } \\
\text { products }(g 2)\end{array}$} & $0.959 * * *$ & $0.833 * * *$ & $0.887 * * *$ & $0.853 * * *$ & $0.963 * * *$ & $0.706 * * *$ & $0.932 * * *$ & $0.826^{* * *}$ \\
\hline & $(0.013)$ & $(0.034)$ & $(0.042)$ & -0.018 & $(0.03)$ & $(0.084)$ & $(0.059)$ & $(0.028)$ \\
\hline \multirow[t]{2}{*}{ Located in the capital } & 0.989 & -0.13 & 0.950 & NA & $3.990^{*}$ & 3.064 & 10.083 & NA \\
\hline & $(0.854)$ & $(1.231)$ & $(5.161)$ & & (1.9) & (4.309) & $(8.525)$ & \\
\hline \multirow[t]{2}{*}{$\begin{array}{l}\text { Foreign owned }(10 \% \text { or } \\
\text { more })\end{array}$} & $-3.962 * * *$ & -0.275 & $6.672 *$ & 1.655 & -3.441 & -2.318 & 2.112 & -3.048 \\
\hline & $(0.905)$ & $(0.889)$ & (3.884) & $(1.181)$ & $(3.682)$ & (1.718) & $(5.949)$ & $(2.51)$ \\
\hline 2-digit industry dummies & Yes & Yes & Yes & Yes & Yes & Yes & Yes & Yes \\
\hline Time dummies & No & Yes & No & Yes & No & Yes & No & Yes \\
\hline R-squared & 0.83 & 0.27 & 0.632 & 0.441 & 0.785 & 0.163 & 0.615 & 0.369 \\
\hline Number of firms & 1,415 & 2,049 & 208 & 2,532 & 1,415 & 652 & 119 & 1,353 \\
\hline \multicolumn{9}{|c|}{ Source: Authors' elaboration based on country studies. } \\
\hline \multicolumn{9}{|c|}{$\begin{array}{l}\text { Notes: Product innovators are firms that have introduced product innovations. Process innovators are firms that have introduced process innovations or } \\
\text { organizational change innovations. Product only innovators are firms that are product innovators but not process innovators. Process only innovators are firms } \\
\text { that are process innovators but not product innovators. Product or process innovators are firms that are product innovators or process innovators. Product and } \\
\text { process innovators are firms that are both product innovators and process innovators. }\end{array}$} \\
\hline \multicolumn{9}{|c|}{$\begin{array}{l}\text { Robust standard errors in parentheses. Significance level: *** 1\%,**5\%, and * } 10 \% \text {. In the case of Uruguay was not possible to differentiate whether the firm } \\
\text { was located or not in the capital region }\end{array}$} \\
\hline
\end{tabular}

With respect to the control variables, while location has almost no effect on employment growth, foreign ownership induces employment growth in Costa Rica and has a negative coefficient in Argentina. In general, there are no differences between the results for the whole sample and those for small firms.

The analysis dividing manufacturing firms according to the innovation intensity of their respective sectors presents similar results (see Table A.4 in the Annex) to those described so far. In the three countries considered (Argentina, Chile, and Uruguay) and for both sub-samples, the coefficient for the effect of sales due to new products $\left(g_{2}\right)$ exhibits positive values quite close to unity. As before, process innovation has a negative impact on both samples in the case of Uruguay and has a negative effect on employment growth in the high-tech sector in Chile only.

We know from the previous discussion that OLS results might be biased if innovation outcome variables are correlated with productivity shocks or omitted price growth is captured in the error term of equation (6). However, we also know that the most likely sign for this bias is 
negative; thus, OLS results might produce lower-bound results. In order to control for this problem, we use instrumental variable techniques. Ideally, we should have used the same set of instruments in each country; however, differences in how the surveys are designed at the country level made this impossible. Thus, we use the following set of country-specific instruments. For Argentina, we use whether the firm has some knowledge (but is not necessarily a user) of public support programs for innovation. We think that this variable is more related to the coverage and diffusion of the public support system than to the actual innovation activities carried out by the firms.

In the case of Chile, we use innovation obstacles averaged at the regional levels but across all sectors in the same region, controlling for the strength of the regional innovation system where the firm operates. In the case of Costa Rica, we use the increase in the range of goods, while in the case of Uruguay we also use the increased in the range of goods. This is the same preferred instrument as in Harrison et al. (2008). In both countries, this variable is coded as zero if innovation is not relevant for the range of goods and services produced, one if the impact of innovation on the range is low, two if it is medium, and three if it is high. This is a variable that is clearly related to product innovation. However, to be a valid instrument it needs to have no correlation with the growth rates of the prices of new products relative to the prices of old products. Two other related questions in the surveys ask the firms about the impact of innovation on increased market share and on the improved quality of goods. So, given this we believe that the increase in the range of products is related to an increase in demand for reasons other than changes in product prices and quality. Thus, we expect this instrument to be uncorrelated with changes in the price of new products compared to old products. In further robustness checks, we also test for the validity of the different instruments.

When we estimate the same equation using instrumental (IV), we observe that the coefficient on $g 2$ (Table 6) moves upward compared to the results just presented. This is consistent with a downward bias in the OLS estimate. Although a coefficient greater than one offers evidence that new products are produced less efficiently than old products, we find (with the exception of small firms in Chile) this evidence to be tenuous, given that the estimate is not statistically different than one. To summarize, there is no evidence of a displacement effect on employment after a product innovation, only a creation effect due to demand enlargement. The 
results show that process innovation has only negative effects on employment in the case of the whole sample in Uruguay (and a positive effect only in Costa Rica).

There are two plausible interpretations for this result. First, a process innovation may not generate important productivity gains; hence, there is no displacement effect on employment. Second, a process innovation may generate productivity gains (displacement effect), which induce a demand enlargement through market competition (creation effect). In the end, the creation effect on employment compensates the displacement effect on employment.

The IV results of the basic model are almost identical for SMEs (right panel) and for high- and low-tech samples (Table A.5 in the Annex). The results are qualitatively similar. Perhaps the most interesting result is that in the case of Uruguay the displacement effect of process innovation is stronger in large firms and in the high-tech sector.

Table 6. Employment Growth - All Manufacturing and Small Manufacturing Firms Dependent variable: l-(g1-П) - IV estimation

\begin{tabular}{|c|c|c|c|c|c|c|c|c|}
\hline \multirow{2}{*}{$\begin{array}{l}\text { Sector } \\
\text { Regression }\end{array}$} & \multicolumn{4}{|c|}{ All firms in manufacturing } & \multicolumn{4}{|c|}{ Small firms in manufacturing } \\
\hline & AR-IV & CH-IV & CR-IV & UY-IV & AR-IV & CH-IV & CR-IV & UY-IV \\
\hline \multirow[t]{2}{*}{ Constant } & -0.994 & -2.016 & $-12.160 * *$ & $1.402 * *$ & -0.684 & -2.125 & -7.571 & 0.267 \\
\hline & (3.236) & $(3.00)$ & $(5.170)$ & -0.662 & $(4.44)$ & $(4.701)$ & $(6.088)$ & -0.907 \\
\hline \multirow[t]{2}{*}{ Process only innovator $(d)$} & 1.398 & 0.333 & $18.413^{*}$ & $-2.716^{* *}$ & -2.542 & -3.38 & 15.415 & -2.595 \\
\hline & $(1.673)$ & $(2.572)$ & $(10.076)$ & -1.104 & $(2.691)$ & $(2.921)$ & $(12.655)$ & -1.772 \\
\hline \multirow[t]{2}{*}{ Sales growth due to new products $(g 2)$} & $1.170^{* * *}$ & $1.751^{* * *}$ & $1.015^{* * *}$ & $0.961 * * *$ & $1.140 * * *$ & $2.141^{*}$ & $1.051 * * *$ & $0.998 * * *$ \\
\hline & $(0.125)$ & $(0.653)$ & $(0.050)$ & -0.04 & $(0.218)$ & $(1.205)$ & $(0.068)$ & -0.063 \\
\hline \multirow[t]{2}{*}{ Located in the capital } & 1.623 & -0.36 & 1.361 & NA & $4.690^{*}$ & 5.208 & 7.194 & NA \\
\hline & $(0.998)$ & $(1.449)$ & $(5.503)$ & & $(2.22)$ & $(4.699)$ & $(11.113)$ & \\
\hline \multirow[t]{2}{*}{ Foreign owned ( $10 \%$ or more) } & $-5.467 * * *$ & 0.048 & $6.680^{*}$ & 1.371 & -5.412 & 0.865 & -0.319 & -3.162 \\
\hline & $(1.349)$ & $(1.04)$ & $(3.843)$ & -1.186 & $(5.132)$ & (3.394) & $(6.049)$ & -2.502 \\
\hline 2-digit industry dummies & Yes & Yes & Yes & Yes & Yes & Yes & Yes & Yes \\
\hline Time dummies & No & Yes & No & Yes & No & Yes & No & Yes \\
\hline $\mathrm{F}$ test, g2 equation & 14.32 & 35.91 & 78.16 & 170.8 & 6.2 & 6.94 & 51.12 & 89.62 \\
\hline Pvalue & 0.002 & 0.000 & 0.000 & 0.000 & 0.013 & 0.000 & 0.000 & 0.000 \\
\hline Davidson-M acKinnon test of exogeneity for $g \hat{z}$ & 3.319 & 2.71 & 13.79 & 10.39 & 0.784 & 2.23 & 7.15 & 10.66 \\
\hline Pvalue & 0.069 & 0.0999 & 0.00027 & 0.0013 & 0.376 & 0.1354 & 0.0088 & 0.0011 \\
\hline R-squared & 0.785 & 0.2471 & 0.652 & 0.42 & 0.724 & 0.1392 & 0.583 & 0.338 \\
\hline Number of firms & 1,415 & 2,049 & 208 & 2,532 & 417 & 652 & 119 & 1,353 \\
\hline \multicolumn{9}{|c|}{ Source: Authors' elaboration based on country studies. } \\
\hline \multicolumn{9}{|c|}{$\begin{array}{l}\text { Notes: Product innovators are firms that have introduced product innovations. Process innovators are firms that have introduced process innovations or organizational change } \\
\text { innovations. Product only innovators are firms that are product innovators but not process innovators. Process only innovators are firms that are process innovators but not } \\
\text { product innovators. Product or process innovators are firms that are product innovators or process innovators. Product and process innovators are firms that are both product }\end{array}$} \\
\hline \multicolumn{9}{|c|}{$\begin{array}{l}\text { Robust standard errors in parentheses. Significance level: *** } 1 \%, * * 5 \% \text {, and } * 10 \% \text {. In the case of Uruguay was not possible to differentiate whether the firm was located or not } \\
\text { in the capital region }\end{array}$} \\
\hline
\end{tabular}




\subsection{Robustness Checks on the Relationship between Innovation and Employment}

Several robustness checks to evaluate the sensitivity of the results were performed in each of the country studies. ${ }^{14}$ First, we included additional instruments to test exogeneity of instruments using a Sargan-Hansen overidentification test. In the case of Argentina, the additional instruments used are an indicator of positive $R \& D$ investment in each year (continuous $R \& D$ dummy) and a set of indicators related with the life cycle of the main product (product life cycle dummies). Continuous R\&D is likely to be correlated with time-invariant firm attributes rather than productivity shocks. Product life cycle dummies may capture reasons for introducing new products unrelated to productivity shocks or growth in prices for new products. Thus, both seem like sensible instrument candidates. In the case of Costa Rica, the previous increase in productive capacity was used as an additional instrument. Based on the accelerator theory, it could be argued that before an increase in the demand of the goods produced, the firm has the option to increase its production by increasing its productive capacity. Thus, the production of new goods would be related to the increase in the productive capacity, but the increase in productive capacity would not necessarily be correlated to productivity shocks. In the case of Uruguay, the development of new markets was used as an additional instrument. In the questionnaire, firms are asked if the innovation helped maintain or increased market share. The opening up of new markets is expected to be related to the development of new products and an increase in demand for reasons other than changes in product prices and quality, complementing the increased range of goods that could be related to a change in price. Finally, in Chile the same instruments as before were used. In every case, the test of excluded instruments in the first stage suggests that the model is identified and weak instruments are not a concern. In addition, the Sargan-Hansen test does not reject exogeneity of the instruments. These results provide additional evidence of the validity of the originally chosen instrument(s).

Second, a model in which both $\mathrm{g} 2$ and process innovation are endogenous was estimated. In every case, when including the estimation assuming $d$ as an endogenous variable, the Davidson-MacKinnon test of exogeneity does not reject the null hypothesis for the variable;

\footnotetext{
${ }^{14}$ To simplify the exposition, we focus on the impact of innovation on employment.
} 
hence, this variable can be considered an exogenous variable. Additionally, the results of the Sargan test indicate no problems with respect to the validity of the instruments.

Third, an interaction between g2 and a dummy that is equal to 1 if product innovation occurs together with process innovation was added as an additional covariate. In the case of Argentina, the interaction between knowledge of support for innovation activity and the product and process innovator dummy as an additional instrument was used. For Uruguay, the instruments used are "increased range of good," "development of new market," and their interactions with the products and process innovation dummy. Again, in Chile, the same three instruments were used. Unfortunately, in the case of Costa Rica it was not possible to check for changes in the slope, since there were no firms in the sample that meet such a condition. Even though the estimated coefficient on g2 increases, the interaction is not significant, concluding that there is no compelling evidence to treat product and process innovators separately from product innovators. In the case of Uruguay, there is only weak evidence that the positive impact on labor growth of the introduction of new products is weaker when this innovation is introduced together with a process innovation. Process innovation only continues to have, in general, a negative impact on labor growth, but in some cases the coefficient is not significantly different from zero. ${ }^{15}$

\subsection{Decomposition of Employment Growth}

An interesting way to summarize the evidence obtained with our estimates is to use them to decompose the employment growth observed in each country (and type of firm) over three different components. Using our preferred specification (i.e., equation [6] with IV), we can write employment growth for each firm as follows:

\footnotetext{
15 In the cases of Costa Rica and Argentina, a more restrictive definition for sales of new products was also implemented by excluding new goods sold by the firm that were already sold in the market by other firms. The reported results show that the new estimates were consistent with the previous results. Finally, in Argentina the estimation of innovation-employment model under non-constant returns to scale was performed as part of the robustness checks. The main result is that joint identification of efficiency and scale parameters is quite complicated, and assuming constant returns to scale is a sensible working assumption given those constraints.
} 


$$
\begin{gathered}
l=\left[\sum_{j}\left(\hat{\alpha}_{0}+\hat{\alpha}_{0 j}\right) i n d_{j}+\hat{\alpha}_{1} d\right]+\left[1-1\left(g_{2}>0\right)\right]\left(g_{1}-\pi_{1}\right)+1\left(g_{2}>0\right)\left(g_{1}-\pi_{1}+\hat{\beta} g_{2}\right) \\
+\hat{u}
\end{gathered}
$$

with the same notations as before and with $i n d_{j}$ denoting the industry dummies and $\hat{\alpha}_{0 j}$ their estimated coefficients. For a given firm, the first component $\left[\sum_{j}\left(\hat{\alpha}_{0}+\hat{\alpha}_{0 j}\right) i n d_{j}+\widehat{\alpha_{1}} d\right]$ measures the change in its employment attributable to the (industry-specific) productivity trend in production of old products plus the firm specific productivity growth due to process innovations in the production of old products; the second component $\left(\left[1-1\left(g_{2}>0\right)\right]\left(g_{1}-\right.\right.$ $\left.\pi_{1}\right)$ ) corresponds to the employment change associated with output growth of old products for firms that do not introduce new products; and finally, the fourth one $1\left(g_{2}>0\right)\left(g_{1}-\pi_{1}+\hat{\beta} g_{2}\right)$ gives the net contribution of product innovation (i.e., contribution after allowing for any substitution of new products for old products). The last term $(\hat{u})$ is a zero-mean residual component.

Table 7 reports the results of applying this decomposition to the four country samples using the proportion of firms and averages presented in Table 1 with the coefficients obtained in Table 6. First, in the case of all manufacturing firms (top panel), product innovations are an important source of firm-level employment growth. This is true even in situations of aggregate employment destruction, as in the cases of Argentina and Uruguay. Specifically, in these two cases, the main driver for the destruction of employment is the contraction in the production of old products. Finally, we observe that productivity growth associated with the production of old products normally leads to employment destruction, with the exception of a modest positive impact on employment in the case of Uruguay.

For small firms (bottom panel of Table 7), with respect to product innovation we observe that, with the sole exception of Uruguay, this type of innovation is an important source of employment growth at the firm level. The results for the output of old products and the productivity trend present a very similar picture to that exhibited by the whole sample of manufacturing firms. 
Table 7. Decomposition of Employment Growth (from IV estimates) - All Manufacturing and Small Firms Manufacturing

\begin{tabular}{|c|c|c|c|c|}
\hline Manufacturing & $\mathrm{AR}$ & $\mathrm{CH}$ & $\mathrm{CR}$ & UY \\
\hline Firms employment growth & -4.0 & -0.2 & 3.3 & -0.7 \\
\hline Productivity trend and process innovation & -0.2 & -7.1 & -7.2 & 1.0 \\
\hline Output growth of old products & -4.7 & -0.3 & 2.9 & -1.9 \\
\hline Product Innovation & 0.9 & 7.2 & 7.6 & 0.2 \\
\hline Small manufacturing & $\mathrm{AR}$ & $\mathrm{CH}$ & $\mathrm{CR}$ & UY \\
\hline Firms employment growth & -3.5 & 1.4 & 3.6 & -3.7 \\
\hline Productivity trend and process innovation & 2.2 & -5.0 & -5.6 & 0.4 \\
\hline Output growth of old products & -6.1 & 1.2 & 2.8 & -3.8 \\
\hline Product Innovation & 0.4 & 5.3 & 6.4 & -0.3 \\
\hline
\end{tabular}

Source: Authors' elaboration based on country studies. IV estimates.

Notes: Argentina (AR)-Innovation Survey 1998-2001; Chile (CH): pooled regressions for the innovation surveys 1995, 1998, 2001, 2007; Costa Rica (CR): Innovation survey 2006-2007. Uruguay: pooled regressions for the surveys 1998-2000, 2001-2003 and 2004-2006.

The decomposition for the samples of low- and high-tech sector firms shows, first, that the drop in output of old product for non-innovator firms is mostly responsible for the almost ubiquitous drop in employment (with the sole exceptions of slight employment growth in hightech sectors in both Chile and Uruguay). In this setting, Table 8 shows a consistent positive effect of product innovation for both low- and high-tech sectors, with the sole exception of the high-tech sector in Argentina. In the case of Argentina, while product innovation has a negative effect on employment growth in the high-tech sector, it has a positive effect on employment growth in the low-tech sector. In both Chile and Uruguay, the positive effects on employment growth due to product innovation are present in both the high- and the low-tech sectors, although the impacts are always larger in the former ones. 
Table 8. Decomposition of Employment Growth (from IV estimates) - High- and Low-Tech

\begin{tabular}{|c|c|c|c|c|c|c|}
\hline & $\begin{array}{c}\text { AR } \\
\text { High-tech }\end{array}$ & $\begin{array}{c}\text { AR } \\
\text { Low-tech }\end{array}$ & $\begin{array}{c}\text { CH } \\
\text { High-tech }\end{array}$ & $\begin{array}{c}\mathrm{CH} \\
\text { Low-tech }\end{array}$ & $\begin{array}{c}\text { UY } \\
\text { High-tech }\end{array}$ & $\begin{array}{c}\text { UY } \\
\text { Low-tech }\end{array}$ \\
\hline Firms employment growth & -4.4 & -3.4 & 0.1 & -0.1 & 0.3 & -2.1 \\
\hline Productivity trend and process innovation & 5.6 & 0.0 & -7.7 & -4.4 & 1.2 & 0.8 \\
\hline Output growth of old products & -5.4 & -3.7 & -0.1 & -0.5 & -1.2 & -2.9 \\
\hline Product Innovation & -4.6 & 0.3 & 7.9 & 4.8 & 0.3 & 0.1 \\
\hline
\end{tabular}

\section{Innovation Effects on Skill Composition}

In this section, we estimate equations (7) and (8), controlling for fixed effects at the industry level. Non-observable characteristics can be correlated with innovation variables; hence, as in the previous section, our preferred strategy relies on the use of an instrumental variables approach. Given the validity of the instruments used so far, we will use the same set used in the previous section. Specifically, the share of skilled labor force in a given firm is measured as the percentage of professionals and technicians working for that firm in a certain period. Unfortunately, the analysis in this section is restricted to Argentina, Costa Rica, and Uruguay. We could not consider Chile in the analysis because innovation surveys in these countries do not report the classification of employment by skills.

\subsection{Descriptive Statistics}

Table 9 shows descriptive statistics for the available data on the share of skilled workers for Argentina, Costa Rica, and Uruguay, distinguishing by type of innovative firm. The mean share of skilled labor in the manufacturing sector is slightly above 30 percent, with the exception of Uruguay (9.5 percent). While product innovators have the highest share, the lowest is observed in either non-innovators (Argentina and Uruguay) or process-only innovators (Uruguay). That table also offers statistics for real growth rates of employment for each type of labor by type of firm. In all the countries considered, we observe that skilled labor grows at a higher pace than unskilled labor (e.g., 1.4 percent vs. 5.3 percent in the case of Argentina, 4.5 percent vs. 4.4 percent in the case of Costa Rica, and 10.2 percent vs. 5.1 percent in the case of Uruguay). 
Growth rates for both types of labor are normally higher for innovators (whether process or product innovators). These general trends are consistent with a generalized process of skills upgrading in manufacturing in the three countries considered and also with some sort of skillbiased technical change driven by both process and product innovations.

Taken at face value, this might suggest a skill bias due to the introduction of innovations. Nevertheless, to fully assess the existence of skill bias due to the introduction of innovation, a model such as the one suggested in equation (6) is needed. Additionally, whether or not the coefficients found for each type of labor are statistically different must be assessed.

Table 9. Descriptive Statistics, Employment Quality - All Manufacturing Firms

\begin{tabular}{|c|c|c|c|}
\hline Manufacturing firms & Argentina & Costa Rica & Uruguay \\
\hline \multicolumn{4}{|l|}{ Share of skilled labor } \\
\hline All firms & 34.0 & 32.3 & 9.5 \\
\hline Non-innovators (no process or product innovations) & 28.0 & 33.0 & 7.4 \\
\hline Process only innovators (non-product innovators) & 34.0 & 25.2 & 10.4 \\
\hline Product innovators & 39.0 & 32.5 & 12.5 \\
\hline \multicolumn{4}{|l|}{ Employment (total) growth (\%) } \\
\hline All firms & -4.0 & 3.3 & 9.5 \\
\hline Non-innovators (no process or product innovations) & -6.0 & 3.5 & 3.3 \\
\hline Process only innovators (non-product innovators) & -3.9 & 7.4 & 6.2 \\
\hline Product innovators & -2.5 & 3.0 & 7.6 \\
\hline \multicolumn{4}{|l|}{ Skilled labor growth (\%) } \\
\hline All firms & -1.4 & 4.5 & 10.2 \\
\hline Non-innovators (no process or product innovations) & -3.9 & 6.1 & 6.3 \\
\hline Process only innovators (non-product innovators) & -1.1 & 3.5 & 13.4 \\
\hline Product innovators & 0.2 & 4.1 & 14.1 \\
\hline \multicolumn{4}{|l|}{ Unskilled labor growth (\%) } \\
\hline All firms & -5.3 & 4.4 & 5.1 \\
\hline Non-innovators (no process or product innovations) & -6.7 & 2.2 & 4.1 \\
\hline Process only innovators (non-product innovators) & -4.6 & 13.0 & 5.2 \\
\hline Product innovators & -4.6 & 4.5 & 6.8 \\
\hline \multicolumn{4}{|l|}{ Source: Authors' elaboration based on country studies. } \\
\hline \multicolumn{4}{|c|}{$\begin{array}{l}\text { Notes: Argentina (AR)-Innovation Survey 1998-2001; Costa Rica (CR): Innovation survey 2006-2007 Uruguay: pooled regressions } \\
\text { for the surveys 2001-2003, 2004-2006 and 2007-2009. }\end{array}$} \\
\hline \multicolumn{4}{|c|}{$\begin{array}{l}\text { Product innovators are firms that have introduced product innovations. Process only innovators are firms that have introduced } \\
\text { process innovations or organizational change innovations excluding product innovators. Non-innovators are firms not classified as } \\
\text { product or process innovators. Sample: Firms with less than } 50 \text { employees and with information in all the relevant variables for the } \\
\text { empirical analysis. (a) Sales growth for each type of firm is the average of the variable } g \text { and averages for old and new products are } \\
\text { the averages of variables g1 and g2, respectively, and (b) prices computed for a set of industries and assigned to firms according to } \\
\text { their activity. }\end{array}$} \\
\hline
\end{tabular}




\subsection{Econometric Results for Skill Composition}

In this section, we present the results for the model in equations (7) and (8). The dependent variables are the employment growth rate of type $q_{j}$ labor minus sales growth rate $(l q j-(g 1-\pi))$ for each type of labor (i.e., skilled and unskilled labor), described below. The specifications include the process innovation dummy, $d$, sales growth rate of new products, $g 2$, a dummy controlling for the foreign ownership of the firm, whether the firm is located in the capital region of the country, and a constant capturing the productivity trend. The estimations also include industry fixed effects (at 2-digit level). Given the problem with the potential endogeneity of the innovation variables, we only report the IV estimates. ${ }^{16}$

The results summarized in Table 10 suggest some interesting patterns regarding the impacts of innovation on skills composition of the workforce. First, product innovation is always significant and close to 1 . We also find that the coefficient associated with the sales growth of new products is systematically about 20 percent larger for skilled labor than unskilled labor in the cases of Argentina and Uruguay. On the other hand, the coefficients of product innovation are rather similar in the case of Costa Rica. With regard to the process innovation dummies, the same ones are not statistically significant in the case of Argentina (although numerically larger for skilled labor), negatively significant for unskilled labor in the case of Uruguay and, surprisingly, positive and significant in the case of Costa Rica. In summary, there seems to be skill-biased product and process innovation both in Argentina and Uruguay. In Costa Rica, on the other hand, we do not find any strong evidence of skill-biased technological change. These results are also very similar to those for small firms (Table 11).

\footnotetext{
${ }^{16}$ For comparison purposes, the OLS result can be found in Tables A.6, A.7, and A.8 in the Annex.
} 
Table 10. Employment Growth by Type of Labor (skilled and unskilled) Manufacturing Firms - IV Estimation

\begin{tabular}{|c|c|c|c|c|c|c|}
\hline \multirow{2}{*}{$\begin{array}{l}\text { Country } \\
\text { Regression }\end{array}$} & \multicolumn{2}{|c|}{ Argentina } & \multicolumn{2}{|c|}{ Costa Rica } & \multicolumn{2}{|c|}{ Uruguay } \\
\hline & $\begin{array}{c}\text { Skilled } \\
\text { IV }\end{array}$ & $\begin{array}{c}\text { Unskilled } \\
\text { IV }\end{array}$ & $\begin{array}{c}\text { Skilled } \\
\text { IV }\end{array}$ & $\begin{array}{c}\text { Unskilled } \\
\text { IV }\end{array}$ & $\begin{array}{c}\text { Skilled } \\
\text { IV }\end{array}$ & $\begin{array}{c}\text { Unskilled } \\
\text { IV }\end{array}$ \\
\hline \multirow[t]{2}{*}{ Constant } & -1.179 & -1.975 & $-11.580 * *$ & $-12.283 * *$ & $2.934^{*}$ & 0.225 \\
\hline & -4.353 & -3.848 & $(5.873)$ & $(6.099)$ & $(1.748)$ & $(1.100)$ \\
\hline \multirow[t]{2}{*}{ Process only innovator $(d)$} & 3.048 & 2.448 & 10.465 & $26.260 * *$ & 2.379 & $-3.373 *$ \\
\hline & -2.291 & -2.01 & $(11.446)$ & $(11.887)$ & $(2.822)$ & $(1.780)$ \\
\hline \multirow[t]{2}{*}{ Sales growth due to new products $(g 2)$} & $1.308 * * *$ & $1.126^{* * *}$ & $1.010 * * *$ & $1.020 * * *$ & $1.087 * * *$ & $0.929 * * *$ \\
\hline & $(0.174)$ & $(0.153)$ & $(0.057)$ & $(0.059)$ & $(0.120)$ & $(0.075)$ \\
\hline Located in the capital & Yes & Yes & Yes & Yes & No & No \\
\hline Foreign owned ( $10 \%$ or more) & Yes & Yes & Yes & Yes & Yes & Yes \\
\hline 2-digit industry dummies & Yes & Yes & Yes & Yes & Yes & Yes \\
\hline Time dummies & No & No & No & No & Yes & Yes \\
\hline F test, $g 2$ equation & 11.47 & 11.47 & 78.16 & 78.16 & 64.87 & 64.87 \\
\hline Pvalue & 0.001 & 0.001 & 0.00 & 0.00 & 0.00 & 0.00 \\
\hline Davidson-MacKinnon test of exogeneity for $g 2$ & 5.99 & 1.43 & 17.27 & 6.23 & 5.37 & 1.16 \\
\hline Pvalue & 0.02 & 0.23 & 0.00 & 0.01 & 0.02 & 0.28 \\
\hline Number of firms & 1,209 & 1,209 & 208 & 208 & 1037 & 1037 \\
\hline
\end{tabular}

Source: Authors' elaboration based on country studies.

Notes: Product innovators are firms that have introduced product innovations. Process innovators are firms that have introduced process innovations or organizational change innovations. Product only innovators are firms that are product innovators but not process innovators. Process only innovators are firms that are process innovators but not product innovators. Product or process innovators are firms that are product innovators or process innovators. Product and process innovators are firms that are both product innovators and process innovators.

Robust standard errors in parentheses. Significance level: *** 1\%,**5\%, and * 10\%. In the case of Uruguay was not possible to differentiate whether the firm was located or not in the capital region. For Uruguay, estimates also included whether the firms was fully foreign owned.

Endogenous variable g2. Instruments used: AR: knowledge of public support for innovation activities; CR: increased range of goods and increase in productive capacity, UY: Increased range of goods and services and new markets. 


\section{Table 11. Employment Growth by Type of Labor (skilled and unskilled) - Small Manufacturing Firms - IV Estimation}

\begin{tabular}{|c|c|c|c|c|c|c|}
\hline $\begin{array}{l}\text { Sector: S mall Manufacturing } \\
\text { Country }\end{array}$ & & ina & & ica & & \\
\hline Regression & $\begin{array}{c}\text { Skilled } \\
\text { IV }\end{array}$ & $\begin{array}{l}\text { Unskilled } \\
\text { IV }\end{array}$ & $\begin{array}{l}\text { Skilled } \\
\text { IV }\end{array}$ & $\begin{array}{l}\text { Unskilled } \\
\text { IV }\end{array}$ & $\begin{array}{c}\text { Skilled } \\
\text { IV }\end{array}$ & $\begin{array}{l}\text { Unskilled } \\
\text { IV }\end{array}$ \\
\hline Constant & $\begin{array}{l}-3.184 \\
(7.263)\end{array}$ & $\begin{array}{l}-3.581 \\
(6.159)\end{array}$ & $\begin{array}{l}-7.479 \\
(6.500)\end{array}$ & $\begin{array}{l}-7.132 \\
(7.487)\end{array}$ & $\begin{array}{c}3.418 \\
(2.282)\end{array}$ & $\begin{array}{l}-1.132 \\
(1.500)\end{array}$ \\
\hline Process only innovator $(d)$ & $\begin{array}{l}-3.696 \\
(3.887)\end{array}$ & $\begin{array}{c}0.218 \\
(3.025)\end{array}$ & $\begin{array}{c}4.371 \\
(13.512)\end{array}$ & $\begin{array}{c}17.478 \\
(15.563)\end{array}$ & $\begin{array}{c}5.116 \\
(4.965)\end{array}$ & $\begin{array}{l}-3.281 \\
(3.278)\end{array}$ \\
\hline $\begin{array}{l}\text { Sales growth due to new products } \\
\text { (g2) }\end{array}$ & $\begin{array}{l}1.346^{* * *} \\
(0.379)\end{array}$ & $\begin{array}{c}1.075^{* * *} \\
(0.304)\end{array}$ & $\begin{array}{c}1.012 * * * \\
(0.072)\end{array}$ & $\begin{array}{c}1.068 * * * \\
(0.083)\end{array}$ & $\begin{array}{c}0.970 * * * \\
(0.196)\end{array}$ & $\begin{array}{c}0.916^{* * *} \\
(0.129)\end{array}$ \\
\hline Located in the capital & $\begin{array}{c}1.69 \\
(3.211)\end{array}$ & $\begin{array}{l}6.488^{*} \\
(2.863)\end{array}$ & $\begin{array}{c}3.642 \\
(6.458)\end{array}$ & $\begin{array}{c}0.746 \\
(7.439)\end{array}$ & NA & NA \\
\hline Foreign owned ( $10 \%$ or more $)$ & $\begin{array}{l}-0.597 \\
(5.96)\end{array}$ & $\begin{array}{l}-1.166 \\
(4.966)\end{array}$ & $\begin{array}{c}16.448 \\
(11.866)\end{array}$ & $\begin{array}{c}-0.729 \\
(13.667)\end{array}$ & $\begin{array}{c}21.396 \\
(13.623)\end{array}$ & $\begin{array}{c}21.396 \\
(13.688)\end{array}$ \\
\hline $\begin{array}{l}\text { 2-digit industry dummies } \\
\text { Time dummies }\end{array}$ & $\begin{array}{l}\text { Yes } \\
\text { No }\end{array}$ & $\begin{array}{l}\text { Yes } \\
\text { No }\end{array}$ & $\begin{array}{l}\text { Yes } \\
\text { No }\end{array}$ & $\begin{array}{l}\text { Yes } \\
\text { No }\end{array}$ & $\begin{array}{l}\text { Yes } \\
\text { Yes }\end{array}$ & $\begin{array}{l}\text { Yes } \\
\text { Yes }\end{array}$ \\
\hline F test, $g 2$ equation & 4.486 & 4.486 & 51.120 & 51.12 & 32.52 & 32.52 \\
\hline Pvalue & 0.035 & 0.035 & 0.000 & 0.00 & 0.000 & 0.00 \\
\hline Davidson-MacKinnon test of exog & 1.341 & 0.141 & 7.856 & 1.78 & 3.170 & 0.81 \\
\hline Pvalue & 0.247 & 0.707 & 0.006 & 0.1856 & 0.080 & 0.37 \\
\hline Number of firms & 306 & 306 & 208 & 208 & 443 & 443 \\
\hline
\end{tabular}

Source: Authors' elaboration based on country studies.

Notes: Product innovators are firms that have introduced product innovations. Process innovators are firms that have introduced process innovations or organizational change innovations. Product only innovators are firms that are product innovators but not process innovators. Process only innovators are firms that are process innovators but not product innovators. Product or process innovators are firms that are product innovators or process innovators. Product and process innovators are firms that are both Robust standard errors in parentheses. Significance level: *** 1\%, ** 5\%, and *10\%. In the case of Uruguay was not possible to differentiate whether the firm was located or not in the capital region. For Uruguay, estimates also included whether the firms was Endogenous variable g2. Instruments used: AR: knowledge of public support for innovation activities; CR: increased range of goods and increase in productive capacity, UY: Increased range of goods and services and new markets.

The IV estimates for the low-tech sector (Table A.9 in the Appendix) show no evidence of skill bias due to the introduction of innovations. Only in the case of Uruguay is there a higher coefficient for $g 2$ on the unskilled labor in comparison to the skill labor. In the Uruguay hightech sample, there is evidence of skill bias due to the introduction of new products. Throughout the analysis, there is no evidence of any effect on employment or of skill biases due to the introduction of process innovations. 


\subsection{Employment Growth Decomposition}

As in the previous section, we decompose the growth of the employment for each type of labor into three components: the productivity trend in the production of old products (including the effect of process innovation in the production of old products); the change in employment associated with output growth of old products for firms that do not introduce new products; and finally, the net contribution of product innovation (i.e., contribution after allowing for any substitution of new products for old products).

In the case of the whole sample for manufacturing firms, product innovation seems to contribute to the creation of both unskilled (except in the case of Uruguay) and skilled employment (Table 12, top and lower panels, respectively). In Argentina and Uruguay, the effect of product innovation on skilled labor is higher than on unskilled labor. Indeed, while product innovation contributed to 0.1 percent of unskilled employment growth in Argentina, its effect on skilled labor was 3.5 percent. The same is true for Uruguay; product innovation displaced unskilled labor by -0.1 percent, while at the same time it added skilled labor at a rate of 1.5 percent per year. However, the heterogeneity across countries is also important. Indeed, as distinct from the two southern cone countries, in Costa Rica, product innovation has added labor at the same rate for both skilled and unskilled workers.

With respect to productivity trends in the production of old products, the findings across the three countries are more consistent with skill-biased productivity growth. Indeed, in the cases of both Argentina and Costa Rica, productivity growth in old products destroys employment, but the displacement is always larger in the case of unskilled labor. On the other hand, in Uruguay, productivity growth in the production of old products actually creates labor (suggesting that

compensating effects are larger than displacement effects). However, even for Uruguay, productivity growth is associated with higher recruitment of skilled labor. 
Table 12. Decomposition of Unskilled and Skilled Employment Growth Manufacturing Firms - IV Estimation

\begin{tabular}{lllc}
\hline Unskilled labor in manufacturing & AR & CR & UY \\
\hline Firms employment growth & -5.3 & 4.4 & 5.1 \\
$\quad$ Productivity trend and process innovation & -0.7 & -6.4 & 7.1 \\
Output growth of old products & -4.7 & 2.9 & -1.9 \\
Product Innovation & 0.1 & 7.9 & -0.1 \\
\hline \multicolumn{2}{l}{} & $\mathrm{CR}$ & $\mathrm{UY}$ \\
\hline Skilled labor in manufacturing & $\mathrm{AR}$ & 4.5 & 10.2 \\
\hline Firms employment growth & -1.4 & -5.7 & 10.7 \\
Productivity trend and process innovation & -0.2 & 2.9 & -1.9 \\
Output growth of old products & -4.7 & 7.3 & 1.5 \\
Product Innovation & 3.5 & \\
\hline \hline Source: Authors' elaboration based on country studies. IV estimates. & \\
Notes: Argentina (AR)-Innovation Survey 1998-2001; Costa Rica (CR): Innovation survey \\
2006-2007 Uruguay: pooled regressions for the surveys 2001-2003 and 2004-2006.
\end{tabular}

\section{Conclusions}

Despite recent high economic growth, reducing poverty and inequality are high on the policy agenda in Latin America. Considering the key role of employment generation in the reduction of poverty and inequality, it is of particular interest to understand the effects of innovation on employment generation.

In this paper, we have estimated a model based on Harrison et al. (2008) by using a source of comparable and representative data on innovation in manufacturing (by firm size) across four Latin American countries. Our results provide findings on a key yet barely explored topic in the region. They shed new light on the relative roles of displacement and compensation effects of product and process innovation on employment growth in manufacturing.

Our results highlight the fact that individual process innovation accounts for a small share of the changes observed in employment, inducing small displacement effects. More importantly, and fundamental for the search for more inclusive growth patterns in the region, we found that product innovations are an important source of firm-level employment growth. This is true even in situations of aggregate employment destruction. 
We went beyond the received literature by using the same conceptual apparatus to assess the differential effects of innovation on skill composition of employment. Here, we found that although the regression coefficients suggest no clear evidence of a skill bias, the employment growth decompositions generate results that are more consistent with skill-biased product and process innovation. In other words, innovation, in particular product innovation, is good for employment; however, reaping its benefits requires the presence of a workforce with the requisite skills. Results are similar for small and large firms. However, when we looked at different sectors, we found that the skill bias of product innovation is more evident in the case of high-tech sectors. 


\section{References}

Aboal, D., P. Garda, B. Lanzilotta, and M. Perera. 2011. "Innovation, Firm Size, Technology Intensity, and Employment Generation in Uruguay. The Microeconometric Evidence." IDB Technical Notes No. IDB-TN-314. Washington, DC: IDB.

Alvarez, R., J. M. Benavente, R. Campusano, and C. Cuevas. 2011. Employment Generation, Firm Size, and Innovation in Chile. IDB Technical Notes, No. IDB-TN-319. Washington, DC: IDB.

Baldwin, J. 1997. "The Importance of Research and Development for Innovation in Small and Large Canadian Manufacturing Firms.” Statistics Canada Analytical Studies Paper No. 107.

Benavente, J. M. and R. Lauterbach. 2008 “Technological Innovation and Employment: Complements or Substitutes?" The European Journal of Development Research 20(2): $318-29$.

Black, L. and M. Lynch. 2004. "What is driving the New Economy? Benefits from Workplace Innovation." The Economic Journal (114): F97-F116

Bogliacino, F., M. Piva, and M. Vivarelli. 2011. "R\&D and Employment: Some Evidence from European Microdata.” IZA Discussion Papers 5908. Bonn, Germany: IZA.

Coad, A. and R. Rao. 2011. "The Firm-level Employment Effects of Innovations in High-Tech U.S. Manufacturing Industries.” Journal of Evolutionary Economics 21: 255-83.

Crespi, G. and P. Zuñiga. 2012. "Innovation Strategies and Employment in Latin American Firms.” IDB Technical Notes, No. IDB-TN-388. Washington, DC: IDB.

De Elejalde, R., D. Giuliodori, and R. Stucchi. 2011. "Employment Generation, Firm Size and Innovation Microeconometric Evidence from Argentina." IDB Technical Notes, No. IDB-TN-313. Washington, DC: IDB.

Doms, M., T. Dunne, and M. J. Roberts. 1995. " The Role of Technology Use in the Survival and Growth of Manufacturing Plants." International Journal of Industrial Organization Elsevier, 13(4): 523-42.

Evans, D. 1987. “The Relationship between Firm Growth, Size and Age: Estimates for 100 Manufacturing Industries.” The Journal of Industrial Economics 35: N4. 
Fajnzylber, P. and A. M. Fernandes. (2004), "International Economic Activities and the Demand for Skilled Labor; Evidence from Brazil and China.” Policy Research Working Paper Series 3426. Washington, DC: World Bank.

Greenan, N. and D. Guellec. 2000. "Technological Innovation and Employment Reallocation.” Labor 14: 547-90.

Greenhalg, C., M. Longland, and D. Bosworth. 2001. "Technological Activity and Employment in a Panel of UK Firms." Scottish Journal of Political Economy 48: 260-82.

Hall, B. H., F. Lotti, and J. Mairesse. 2008, “Employment, Innovation, and Productivity: Evidence from Italian Microdata." Industrial and Corporate Change 17: 813-39.

Harrison, R., J. Jaumandreu, J. Mairesse, and B. Peters. 2008. “Does Innovation Stimulate Employment? A Firm-Level Analysis Using Comparable Micro-Data from Four European Countries.” NBER Working Paper No. W14216. Cambridge, Mass: National Bureau for Economic Research.

Inter-American Development Bank. 2010. The Age of Productivity, Transforming Economies from the Bottom Up. Development in the Americas. Washington DC: IDB.

Katz, J. 1987. Technology Generation in Latin American Manufacturing Industries. London, United Kingdom: The Macmillan Press Ltd.

Klette, J. and S. Forre. 1995. "Innovation and Job Creation in a Small Open Economy: Evidence from Norwegian Manufacturing Plants, 1982-1992.” Discussion Papers 159. Oslo, Norway: Research Department of Statistics Norway.

Lachenmaier, S. and H. Rottmann. 2011. "Effects of Innovation on Employment: A Dynamic Panel Analysis.” International Journal of Industrial Organization 29: 210-20.

Monge-González, R., J. A. Rodríguez-Alvarez, J. Hewitt, J. Orozco, and K. Ruiz. 2011.

"Innovation and Employment Growth in Costa Rica: A Firm-level Analysis." IDB Technical Notes IDB-TN-318. Washington, DC: IDB.

Olley G. S. and A. Pakes. 1996. "The Dynamics of Productivity in the Telecommunications Equipment Industry." Econometrica 64(6): 1263-97.

Pianta, M. 2006. "Innovation and Employment.” In Fagerberg, J., Mowery, D. and Nelson, R. (eds.) The Oxford Handbook of Innovation. Oxford, United Kingdom: Oxford University Press. 
Spiezia, V. and M. Vivarelli. 2002. "Technical Change and Employment: a Critical Survey." In Greenan, N., Y. L'Horty, and J. Mairesse (eds.) Productivity, Inequality and the Digital Economy: A Transatlantic Perspective. Cambridge, Mass: MIT Press.

Vivarelli, M. 2011. "Innovation, Employment and Skills in Advanced and Developing Countries: A Survey of the Literature.” IDB Technical Notes, No. IDB-TN-351. Washington, DC: IDB. 
Table A.1

\begin{tabular}{|c|c|c|c|c|c|c|}
\hline \multirow[b]{2}{*}{ Manufacturing firms } & \multicolumn{2}{|c|}{ Argentina } & \multicolumn{2}{|c|}{ Chile } & \multicolumn{2}{|c|}{ Uruguay } \\
\hline & Low-tech & High-tech & Low-tech & High-tech & Low-tech & High-tech \\
\hline Number of observations & 672 & 743 & 551 & 1,254 & 1,068 & 1,464 \\
\hline \multicolumn{7}{|l|}{ Distribution of firms (\%) } \\
\hline Non-innovators (no process or product innovat $j$ & 36.3 & 36.1 & 39.4 & 32.9 & 55.8 & 42.6 \\
\hline Process only innovators (non-product innovatos & 15.5 & 15.2 & 5.6 & 4.0 & 16.0 & 21.9 \\
\hline Product innovators & 48.2 & 48.7 & 55.0 & 63.2 & 28.2 & 35.6 \\
\hline Number of employees at the beginning of (each) survey & 276.8 & 193.5 & 220.6 & 214.6 & 75.2 & 102.8 \\
\hline Foreign ownership ( $10 \%$ or more) & 15.8 & 23.3 & 0.1 & 0.1 & 8.7 & 16.4 \\
\hline Located in the capital of the country & 54.3 & 72.4 & 0.5 & 0.5 & 86.6 & 77.0 \\
\hline \multicolumn{7}{|l|}{ Employment growth (\%) (yearly rate) } \\
\hline All firms & -3.4 & -4.4 & -0.1 & 0.1 & -2.1 & 0.3 \\
\hline Non-innovators (no process or product innovat $j$ & -5.7 & -6.4 & 0.4 & 1.0 & -4.6 & -2.2 \\
\hline Process only innovators (non-product innovato] & -3.9 & -3.9 & 3.4 & 1.3 & 0.7 & 2.2 \\
\hline Product innovators & -1.6 & -3.2 & -0.8 & -0.4 & 1.4 & 2.1 \\
\hline \multicolumn{7}{|l|}{ Sales growth (\%) (nominal growth) (a) (yearly rate) } \\
\hline All firms & -7.6 & -10.3 & 4.8 & 7.2 & 3.7 & 6.8 \\
\hline Non-innovators (no process or product innovati & -10.5 & -14.3 & 2.1 & 3.3 & 0.5 & 2.9 \\
\hline Process only innovators (non-product innovatos & -7.1 & -9.1 & 8.1 & 6.4 & 7.9 & 10.5 \\
\hline Product innovators & -5.5 & -7.7 & 6.5 & 9.3 & 7.9 & 9.2 \\
\hline \multicolumn{7}{|l|}{ of which: } \\
\hline Old products & -44.0 & -46.6 & -9.0 & -4.4 & -25.3 & -18.9 \\
\hline New products & 38.5 & 38.9 & 15.4 & 13.7 & 33.2 & 28.1 \\
\hline \multicolumn{7}{|l|}{ Prices growth (\%) ${ }^{(b)}$} \\
\hline All firms & -2.2 & -1.9 & 4.0 & 5.4 & 6.2 & 7.3 \\
\hline Non-innovators (no process or product innovat & -2.3 & -2.3 & 3.5 & 4.0 & 6.3 & 7.4 \\
\hline Process only innovators (non-product innovato] & -2.2 & -1.5 & 7.6 & 3.5 & 5.7 & 7.4 \\
\hline Product innovators & -2.0 & -1.7 & 3.9 & 6.3 & 6.2 & 7.2 \\
\hline
\end{tabular}

Source: Authors' elaboration based on country studies.

Notes: Argentina (AR)-Innovation Survey 1998-2001; Chile (CH): pooled regressions for the innovation surveys 1995, 1998, 2001, 2007; Uruguay: pooled regressions for the surveys 2001-2003, 2004-2006 and 2007-2009.

Product innovators are firms that have introduced product innovations. Process only innovators are firms that have introduced process innovations or organizational change innovations excluding product innovators. Non-innovators are firms not classified as product or process innovators. Sample: Firms with information in all the relevant variables for the empirical analysis. (a) Sales growth for each type of firm is the average of the variable $g$ and averages for old and new products are the averages of variables $g 1$ and g2, respectively, and (b) prices computed for a set of industries and assigned to firms according to their activity. Low-tech and high-tech industries are categories constructed based on their innovation expenditure-to-sales ratios. Industries (considered at the 2-digit level) with ratios below the country median are considered low-tech industries, and industries with ratios above country median are considered high-tech industries 


\section{Table A.2}

\section{Dependent variable: I (Employment growth-yearly)-OLS Estimation, Low tech manufacturing firms}

\begin{tabular}{|c|c|c|c|c|c|c|}
\hline \multirow{2}{*}{$\begin{array}{l}\text { Sector: low-tech manufacturing firms } \\
\text { Regression }\end{array}$} & \multicolumn{2}{|c|}{ Argentina } & \multicolumn{2}{|c|}{ Chile } & \multicolumn{2}{|c|}{ Uruguay } \\
\hline & 1-OLS & 2-OLS & 1-OLS & 2-OLS & 1-OLS & 2-OLS \\
\hline Constant & $\begin{array}{c}-5.826 * * * \\
(1.004)\end{array}$ & $\begin{array}{c}-5.679 * * * \\
(0.999)\end{array}$ & $\begin{array}{l}2.017 * * \\
(0.979)\end{array}$ & $\begin{array}{l}2.002 * * \\
(0.987)\end{array}$ & $\begin{array}{c}-3.652^{* * *} \\
(0.55)\end{array}$ & $\begin{array}{c}-3.9137 * * * \\
(0.57)\end{array}$ \\
\hline Product or process innovator & $\begin{array}{c}4.442^{* * *} \\
(1.228)\end{array}$ & & $\begin{array}{l}1.87 \\
-1.3\end{array}$ & & $\begin{array}{c}8.028 * * * \\
(0.96)\end{array}$ & \\
\hline Product innovator & & $\begin{array}{c}5.542 * * * \\
(1.331)\end{array}$ & & $\begin{array}{r}1.783 \\
(1.393)\end{array}$ & & $\begin{array}{c}12.144 * * * \\
(1.20)\end{array}$ \\
\hline Process only innovator (non-product innovator) & & $\begin{array}{r}1.936 \\
(1.540)\end{array}$ & & $\begin{array}{c}2.238 \\
(2.627)\end{array}$ & & $\begin{array}{c}3.451^{* * *} \\
(1.12)\end{array}$ \\
\hline Real sales growth $(g-\Pi)$ & $\begin{array}{c}0.027 \\
(0.015)\end{array}$ & $\begin{array}{l}0.035^{*} \\
(0.016)\end{array}$ & $\begin{array}{c}0.295^{* * *} \\
(0.048)\end{array}$ & $\begin{array}{c}0.295^{* * *} \\
(0.048)\end{array}$ & $\begin{array}{c}0.152 * * * \\
(0.02)\end{array}$ & $\begin{array}{c}0.201 * * * \\
(0.03)\end{array}$ \\
\hline 2-digit industry dummies & Yes & Yes & Yes & Yes & Yes & Yes \\
\hline Time dummies & No & No & Yes & Yes & Yes & Yes \\
\hline R-squared & 0.062 & 0.071 & 0.171 & 0.171 & 0.243 & 0.275 \\
\hline Number of firms & 672 & 672 & 551 & 551 & 1,068 & 1,068 \\
\hline
\end{tabular}

Source: Authors' elaboration based on country studies.

Notes: Product innovators are firms that have introduced product innovations. Process innovators are firms that have introduced process innovations or organizational change innovations. Product only innovators are firms that are product innovators but not process innovators. Process only innovators are firms that are process innovators but not product innovators. Product or process innovators are firms that are product innovators or process innovators. Product and process innovators are firms that are both product innovators and process innovators. Robust standard errors in parentheses. Significance level: *** 1\%, ** 5\%, and * 10\%. In the case of Argentina includes as additional control foreign ownsership and a dummy that captures whether the firm is located or not in the capital region. 
Table A.3

\section{Dependent variable: I (Employment growth-yearly)-OLS Estimation, High tech manufacturing firms}

\begin{tabular}{|c|c|c|c|c|c|c|}
\hline \multirow{2}{*}{$\begin{array}{l}\text { Sector: high-tech manufacturing firms } \\
\text { Regression }\end{array}$} & \multicolumn{2}{|c|}{ Argentina } & \multicolumn{2}{|c|}{ Chile } & \multicolumn{2}{|c|}{ Uruguay } \\
\hline & 1-OLS & 2-OLS & 1-OLS & 2-OLS & 1-OLS & 2-OLS \\
\hline Constant & $\begin{array}{c}-5.435 * * * \\
(1.084)\end{array}$ & $\begin{array}{c}-5.324 * * * \\
(1.073)\end{array}$ & $\begin{array}{c}2.587 * * * \\
(0.681)\end{array}$ & $\begin{array}{c}2.599 * * * \\
(0.684)\end{array}$ & $\begin{array}{c}-1.723 * * * \\
(0.52)\end{array}$ & $\begin{array}{c}-1.646^{* * *} \\
(0.56)\end{array}$ \\
\hline Product or process innovator & $\begin{array}{c}3.776^{* * * *} \\
(1.066)\end{array}$ & & $\begin{array}{r}0.064 \\
(0.899)\end{array}$ & & $\begin{array}{c}6.694 * * * \\
(0.79)\end{array}$ & \\
\hline Product innovator & & $\begin{array}{c}4.248 * * * \\
(1.175)\end{array}$ & & $\begin{array}{r}0.114 \\
(0.936)\end{array}$ & & $\begin{array}{c}8.485^{* * *} \\
(0.920)\end{array}$ \\
\hline Process only innovator (non-product innovator) & & $\begin{array}{l}2.698^{*} \\
(1.335)\end{array}$ & & $\begin{array}{l}-0.321 \\
(1.772)\end{array}$ & & $\begin{array}{c}2.978 * * * \\
(0.93)\end{array}$ \\
\hline Real sales growth $(g-\Pi)$ & $\begin{array}{l}0.039 * \\
(0.016)\end{array}$ & $\begin{array}{l}0.043^{*} \\
(0.017)\end{array}$ & $\begin{array}{c}0.277 * * * \\
(0.027)\end{array}$ & $\begin{array}{c}0.277 * * * \\
(0.027)\end{array}$ & $\begin{array}{c}0.139 * * * \\
(0.02)\end{array}$ & $\begin{array}{c}0.168 * * * \\
(0.02)\end{array}$ \\
\hline 2-digit industry dummies & Yes & Yes & Yes & Yes & Yes & Yes \\
\hline Time dummies & No & No & Yes & Yes & Yes & Yes \\
\hline R-squared & 0.077 & 0.079 & 0.154 & 0.154 & 0.218 & 0.224 \\
\hline Number of firms & 743 & 743 & 1254 & 1254 & 1,464 & 1,464 \\
\hline
\end{tabular}

Source: Authors' elaboration based on country studies.

Notes: Product innovators are firms that have introduced product innovations. Process innovators are firms that have introduced process innovations or organizational change innovations. Product only innovators are firms that are product innovators but not process innovators. Process only innovators are firms that are process innovators but not product innovators. Product or process innovators are firms that are product innovators or process innovators. Product and process innovators are firms that are both product innovators and process innovators.

Robust standard errors in parentheses. Significance level: *** 1\%, ** 5\%, and * 10\%. In the case of Argentina includes as additional control Foreign Ownsership and a dummy that captures whether the firm is located or not in the capital region. 


\section{Table A.4: Employment Growth. Low- and High-Tech Sectors Dependent Variable: I-(g1-II) - OLS Estimation}

\begin{tabular}{|c|c|c|c|c|c|c|}
\hline Country & $\mathbf{A R}$ & $\mathbf{A R}$ & $\mathbf{C H}$ & $\mathbf{C H}$ & $\mathbf{U Y}$ & $\mathbf{U Y}$ \\
\hline Sector & OLS-Low-tech & OLS-High-tech & OLS-Low-tech & OLS-High-tech & OLS-Low-tech & OLS-High-tech \\
\hline \multirow[t]{2}{*}{ Constant } & $3.140 * *$ & $4.878 * * *$ & $4.113 * * *$ & 1.131 & $2.109 * * *$ & $3.079 * * *$ \\
\hline & $(1.195)$ & $(1.169)$ & $(1.555)$ & $(0.977)$ & $(0.84)$ & $(0.73)$ \\
\hline \multirow[t]{2}{*}{ Process only innovator $(d)$} & -0.196 & -1.059 & -2.457 & $-2.943 * *$ & $-3.474 *$ & $-4.336 * * *$ \\
\hline & $(1.516)$ & $(1.333)$ & $(2.406)$ & $(1.492)$ & $(1.79)$ & $(1.32)$ \\
\hline \multirow{2}{*}{$\begin{array}{l}\text { Sales growth due to new products } \\
\text { (g2) }\end{array}$} & $0.972 * * *$ & $0.945 * * *$ & $0.879 * * *$ & $0.813 * * *$ & $0.864 * * *$ & $0.844 * * *$ \\
\hline & $(0.017)$ & $(0.018)$ & $(0.064)$ & $(0.039)$ & $(0.03)$ & $(0.02)$ \\
\hline \multirow[t]{2}{*}{ Located in the capital } & 0.491 & 1.582 & -2.208 & 0.395 & NA & NA \\
\hline & $(1.255)$ & $(1.151)$ & $(1.775)$ & $(1.026)$ & & \\
\hline \multirow[t]{2}{*}{ Foreign owned ( $10 \%$ or more $)$} & $-4.885^{* *}$ & $-3.243^{* *}$ & -0.897 & 0.061 & 1.218 & 1.889 \\
\hline & $(1.564)$ & $(1.086)$ & $(2.874)$ & $(1.347)$ & $(2.17)$ & $(1.41)$ \\
\hline 2-digit industry dummies & Yes & Yes & Yes & Yes & Yes & Yes \\
\hline Time dummies & No & No & Yes & Yes & Yes & Yes \\
\hline R-squared & 0.818 & 0.844 & 0.281 & 0.268 & 0.441 & 0.441 \\
\hline Number of firms & 672 & 743 & 632 & 1417 & 1,068 & 1,464 \\
\hline \multicolumn{7}{|c|}{ Source: Authors' elaboration based on country studies. } \\
\hline \multicolumn{7}{|c|}{$\begin{array}{l}\text { Notes: Product innovators are firms that have introduced product innovations. Process innovators are firms that have introduced process innovations or } \\
\text { organizational change innovations. Product only innovators are firms that are product innovators but not process innovators. Process only innovators are firms } \\
\text { that are process innovators but not product innovators. Product or process innovators are firms that are product innovators or process innovators. Product and }\end{array}$} \\
\hline
\end{tabular}




\section{Table A.5. Employment Growth. Low- and High-tech Sectors Dependent Variable: I-(g1-II) - IV Estimation}

\begin{tabular}{|c|c|c|c|c|c|c|}
\hline $\begin{array}{l}\text { Sector } \\
\text { Regression }\end{array}$ & $\begin{array}{c}\text { AR } \\
\text { IV-Low-tech }\end{array}$ & $\begin{array}{c}\text { AR } \\
\text { IV-High-tech }\end{array}$ & $\begin{array}{c}\text { CH } \\
\text { IV-Low-tech }\end{array}$ & $\begin{array}{c}\text { CH } \\
\text { IV-High-tech }\end{array}$ & $\begin{array}{c}\text { UY } \\
\text { IV-Low-tech }\end{array}$ & $\begin{array}{c}\text { UY } \\
\text { IV-High-tech }\end{array}$ \\
\hline \multirow[t]{2}{*}{ Constant } & -0.201 & $5.697 * *$ & 1.697 & -2.733 & 1.115 & $1.670^{*}$ \\
\hline & $(1.961)$ & -1.946 & $(4.206)$ & -3.368 & -0.944 & -0.929 \\
\hline \multirow[t]{2}{*}{ Process only innovator $(d)$} & 0.849 & -1.45 & -0.517 & -0.076 & -2.524 & $-2.897 * *$ \\
\hline & $(1.884)$ & $(1.628)$ & $(3.787)$ & -2.835 & -1.813 & -1.407 \\
\hline \multirow[t]{2}{*}{ Sales growth due to new products ( $g 2)$} & $1.105 * * *$ & $0.910 * * *$ & $1.403 *$ & $1.695 * *$ & $0.956^{* * *}$ & $0.958 * * *$ \\
\hline & $(0.066)$ & $(0.071)$ & $(0.846)$ & $(0.728)$ & -0.056 & -0.056 \\
\hline Located in the capital & Yes & Yes & Yes & Yes & No & No \\
\hline Foreign owned ( $10 \%$ or more) & Yes & Yes & Yes & Yes & Yes & Yes \\
\hline 2-digit industry dummies & Yes & Yes & Yes & Yes & Yes & Yes \\
\hline Time dummies & No & No & Yes & Yes & Yes & Yes \\
\hline F test, $g 2$ equation & 8.65 & 5.17 & 13.14 & 23.57 & 94.37 & 81.97 \\
\hline Pvalue & 0.00 & 0.00 & 0.00 & 0.00 & 0.00 & 0.00 \\
\hline $\begin{array}{l}\text { Davidson-MacKinnon } \quad \text { test } \quad \text { of } \\
\text { exogeneity for } g 2\end{array}$ & 4.857 & 0.261 & 0.4293776 & 1.98238 & 4.31788 & 5.496489 \\
\hline Pvalue & 0.028 & 0.61 & 0.5125 & 0.1594 & 0.038 & 0.0192 \\
\hline $\begin{array}{ll}\text { Sargan-Hansen } & \text { test } \\
\text { overidentification } & \end{array}$ & 2.451 & 1.773 & 4.442 & 0.49 & 3.349 & 3.58 \\
\hline Pvalue (degrees of freedom) & 0.874 & 0.939 & 0.1085 & 0.7823 & 0.646 & 0.611 \\
\hline R-squared & 0.811 & 0.748 & 0.2568 & 0.2464 & 0.423 & 0.419 \\
\hline Number of firms & 672 & 743 & 632 & 1417 & 1068 & 1464 \\
\hline
\end{tabular}

Source: Authors' elaboration based on country studies.

Notes: Product innovators are firms that have introduced product innovations. Process innovators are firms that have introduced process innovations or organizational change innovations. Product only innovators are firms that are product innovators but not process innovators. Process only innovators are firms that are process innovators but not product innovators. Product or process innovators are firms that are product innovators or process innovators. Product and process innovators are firms that are both product innovators and process innovators. Low-tech and high-tech industries are categories constructed based on their innovation expenditure-to-sales ratios. Industries (considered at the 2-digit level) with ratios below the country median are considered low-tech industries, and industries with ratios above country median are considered high-tech industries

Robust standard errors in parentheses. Significance level: *** 1\%,** 5\%, and *10\%. In the case of Uruguay was not possible to differentiate whether the firm was located or not in the capital region

Endogenous variable g2. Instruments used: AR: knowledge of public support for innovation activities, continuous R\&D dummy, and product life cycle dummies; CH: obstacles for innovation averaged across firms in the same region; UY: Increased range of goods and services and New markets. 
Table A.6. Employment Growth by Type of Labor (skilled and unskilled)

\section{Manufacturing Firms - OLS Estimation}

\begin{tabular}{|c|c|c|c|c|c|c|}
\hline \multirow{2}{*}{$\begin{array}{l}\text { Country } \\
\text { Regression }\end{array}$} & \multicolumn{2}{|c|}{ Argentina } & \multicolumn{2}{|c|}{ Costa Rica } & \multicolumn{2}{|c|}{ Uruguay } \\
\hline & $\begin{array}{c}\text { Skilled } \\
\text { OLS }\end{array}$ & $\begin{array}{c}\text { Unskilled } \\
\text { OLS }\end{array}$ & $\begin{array}{c}\text { Skilled } \\
\text { OLS }\end{array}$ & $\begin{array}{c}\text { Unskilled } \\
\text { OLS }\end{array}$ & $\begin{array}{c}\text { Skilled } \\
\text { OLS }\end{array}$ & $\begin{array}{c}\text { Unskilled } \\
\text { OLS }\end{array}$ \\
\hline Constant & $\begin{array}{c}.184 * * * \\
(0.947)\end{array}$ & $\begin{array}{l}2.213^{*} \\
(1.060)\end{array}$ & $\begin{array}{c}1.594 \\
(5.514)\end{array}$ & $\begin{array}{l}-3.581 \\
(5.326)\end{array}$ & $\begin{array}{c}5.302 * * * \\
(1.414)\end{array}$ & $\begin{array}{c}0.923 \\
(0.965)\end{array}$ \\
\hline Process only innovator $(d)$ & $\begin{array}{l}-0.152 \\
(1.174)\end{array}$ & $\begin{array}{r}0.845 \\
(1.173)\end{array}$ & $\begin{array}{l}-2.327 \\
(6.907)\end{array}$ & $\begin{array}{c}17.810^{*} \\
(9.753)\end{array}$ & $\begin{array}{l}-0.151 \\
(2.683)\end{array}$ & $\begin{array}{c}-4.120 * * * \\
(1.578)\end{array}$ \\
\hline Sales growth due to new product & $\begin{array}{c}0.962 * * * \\
(0.015)\end{array}$ & $\begin{array}{c}0.953 * * * \\
(0.015)\end{array}$ & $\begin{array}{c}0.850^{* * *} \\
(0.047)\end{array}$ & $\begin{array}{c}0.914 * * * \\
(0.046)\end{array}$ & $\begin{array}{c}0.853 * * * \\
(0.064)\end{array}$ & $\begin{array}{c}0.860 * * * \\
(0.034)\end{array}$ \\
\hline Located in the capital & Yes & Yes & Yes & Yes & NA & NA \\
\hline Foreign owned ( $10 \%$ or more) & Yes & Yes & Yes & Yes & Yes & Yes \\
\hline 2-digit industry dummies & Yes & Yes & Yes & Yes & Yes & Yes \\
\hline Time dummies & No & No & No & No & Yes & Yes \\
\hline R-squared & 0.805 & 0.795 & 0.251 & 0.25 & 0.445 & 0.443 \\
\hline Number of firms & 1209 & 1209 & 208 & 208 & 1037 & 1037 \\
\hline
\end{tabular}

Source: Authors' elaboration based on country studies.

Notes: Product innovators are firms that have introduced product innovations. Process innovators are firms that have introduced process innovations or organizational change innovations. Product only innovators are firms that are product innovators but not process innovators. Process only innovators are firms that are process innovators but not product innovators. Product or process innovators are firms that are product innovators or process innovators. Product and process innovators are firms that are both product innovators and process innovators.

Robust standard errors in parentheses. Significance level: *** 1\%, ** 5\%, and * $10 \%$. In the case of Uruguay was not possible to differentiate whether the firm was located or not in the capital region. For Uruguay, estimates also included whether the firms was fully foreign owned.

\section{Table A.7. Employment Growth by Type of Labor (skilled and unskilled) - Small}

Manufacturing Firms - OLS Estimation

\begin{tabular}{|c|c|c|c|c|c|c|}
\hline \multirow{2}{*}{$\begin{array}{l}\text { Sector S mall Manufacturing } \\
\text { Regression }\end{array}$} & \multicolumn{2}{|c|}{ Argentina } & \multicolumn{2}{|c|}{ Costa Rica } & \multicolumn{2}{|c|}{ Uruguay } \\
\hline & $\begin{array}{l}\text { Skilled } \\
\text { OLS }\end{array}$ & $\begin{array}{l}\text { Unskilled } \\
\text { OLS }\end{array}$ & $\begin{array}{l}\text { Skilled } \\
\text { OLS }\end{array}$ & $\begin{array}{l}\text { Unskilled } \\
\text { OLS }\end{array}$ & $\begin{array}{l}\text { Skilled } \\
\text { OLS }\end{array}$ & $\begin{array}{l}\text { Unskilled } \\
\text { OLS }\end{array}$ \\
\hline Constant & $\begin{array}{l}3.652 \\
-2.274\end{array}$ & $\begin{array}{l}-1.395 \\
-2.632\end{array}$ & $\begin{array}{c}0.004 \\
(6.296)\end{array}$ & $\begin{array}{l}-2.799 \\
(7.247)\end{array}$ & $\begin{array}{c}5.354 * * * \\
(1.915)\end{array}$ & $\begin{array}{c}-0.42 \\
(1.376)\end{array}$ \\
\hline Process only innovator $(d)$ & $\begin{array}{l}-3.874 \\
-2.988\end{array}$ & $\begin{array}{r}0.162 \\
-2.882\end{array}$ & $\begin{array}{l}-6.408 \\
(8.034)\end{array}$ & $\begin{array}{l}11.237 \\
(8.768)\end{array}$ & $\begin{array}{c}3.122 \\
(5.396)\end{array}$ & $\begin{array}{l}-4.014 \\
(2.711)\end{array}$ \\
\hline $\begin{array}{l}\text { Sales growth due to new } \\
\text { products }(g 2)\end{array}$ & $\begin{array}{l}0.991 * * * \\
-0.042\end{array}$ & $\begin{array}{c}0.965 * * * \\
-0.038\end{array}$ & $\begin{array}{c}0.879^{* * *} \\
(0.063)\end{array}$ & $\begin{array}{l}0.991 * * * \\
(0.067)\end{array}$ & $\begin{array}{c}0.687^{* * *} \\
(0.108)\end{array}$ & $\begin{array}{r}0.812^{* * *} \\
(0.065)\end{array}$ \\
\hline Located in the capital & $\begin{array}{l}1.434 \\
-2.829\end{array}$ & $\begin{array}{l}6.408^{*} \\
-2.808\end{array}$ & $\begin{array}{c}6.348 \\
(6.006)\end{array}$ & $\begin{array}{c}2.312 \\
(6.653)\end{array}$ & NA & NA \\
\hline Foreign owned ( $10 \%$ or more $)$ & $\begin{array}{l}-0.548 \\
-4.593\end{array}$ & $\begin{array}{l}-1.15 \\
-4.758\end{array}$ & $\begin{array}{c}19.662 * * \\
(8.809)\end{array}$ & $\begin{array}{c}1.132 \\
(12.218)\end{array}$ & $\begin{array}{c}22.204 * * * \\
(6.444)\end{array}$ & $\begin{array}{c}2.33 \\
(4.680)\end{array}$ \\
\hline $\begin{array}{l}\text { 2-digit industry dummies } \\
\text { Time dummies }\end{array}$ & $\begin{array}{l}\text { Yes } \\
\text { No }\end{array}$ & $\begin{array}{l}\text { Yes } \\
\text { No }\end{array}$ & $\begin{array}{l}\text { Yes } \\
\text { No }\end{array}$ & $\begin{array}{l}\text { Yes } \\
\text { No }\end{array}$ & $\begin{array}{l}\text { Yes } \\
\text { Yes }\end{array}$ & $\begin{array}{l}\text { Yes } \\
\text { Yes }\end{array}$ \\
\hline $\begin{array}{l}\text { R-squared } \\
\text { Number of firms }\end{array}$ & $\begin{array}{c}0.715 \\
306\end{array}$ & $\begin{array}{c}0.729 \\
306\end{array}$ & $\begin{array}{c}0.451 \\
119\end{array}$ & $\begin{array}{c}0.442 \\
119\end{array}$ & $\begin{array}{c}0.675 \\
443\end{array}$ & $\begin{array}{l}0.66 \\
443\end{array}$ \\
\hline
\end{tabular}

Source: Authors' elaboration based on country studies.

Notes: Product innovators are firms that have introduced product innovations. Process innovators are firms that have introduced process innovations or organizational change innovations. Product only innovators are firms that are product innovators but not process innovators. Process only innovators are firms that are process innovators but not product innovators. Product or process innovators are firms that are product innovators or process innovators. Product and process innovators are Robust standard errors in parentheses. Significance level: *** 1\%, ** 5\%, and * $10 \%$. In the case of Uruguay was not possible to differentiate whether the firm was

located or not in the capital region. For Uruguay, estimates also included whether the firms was fully foreign owned. 


\section{Table A.8. Employment Growth by Type of Labor (skilled and unskilled) -}

\section{Low- and High-tech firms - OLS Estimation}

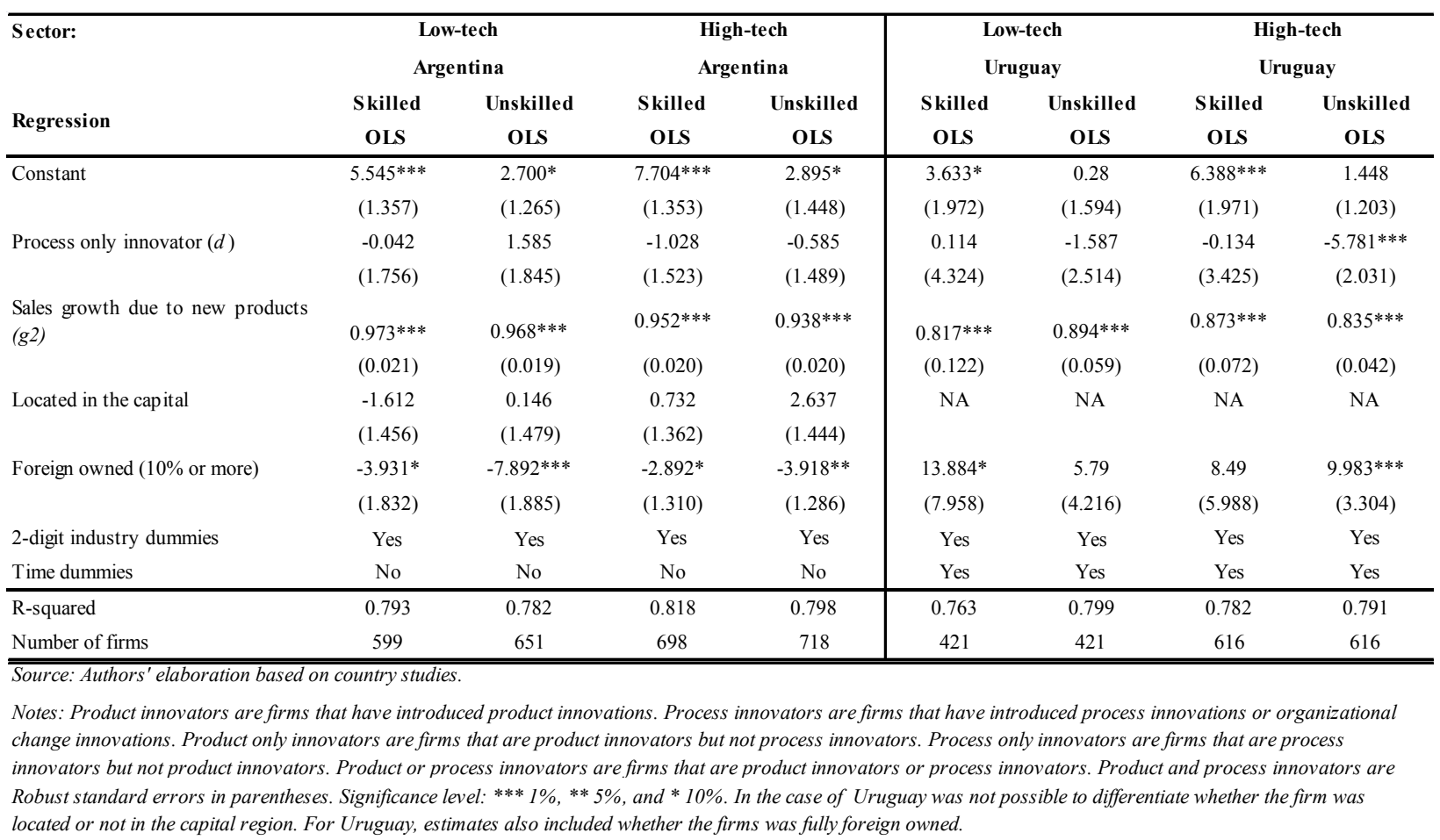




\section{Table A.9. Employment Growth by Type of Labor (skilled and unskilled) -}

\section{Low- and High-tech Firms - IV Estimation}

\begin{tabular}{|c|c|c|c|c|c|c|c|c|}
\hline \multirow{2}{*}{$\begin{array}{l}\text { Sector: } \\
\text { Country } \\
\text { Regression }\end{array}$} & \multicolumn{2}{|c|}{$\begin{array}{l}\text { Low-tech } \\
\text { Argentina }\end{array}$} & \multicolumn{2}{|c|}{$\begin{array}{l}\text { High-tech } \\
\text { Argentina }\end{array}$} & \multicolumn{2}{|c|}{$\begin{array}{l}\text { Low-tech } \\
\text { Uruguay }\end{array}$} & \multicolumn{2}{|c|}{$\begin{array}{l}\text { High-tech } \\
\text { Uruguay }\end{array}$} \\
\hline & $\begin{array}{c}\text { Skilled } \\
\text { IV }\end{array}$ & $\begin{array}{c}\text { Unskilled } \\
\text { IV }\end{array}$ & $\begin{array}{c}\text { Skilled } \\
\text { IV }\end{array}$ & $\begin{array}{c}\text { Unskilled } \\
\text { IV }\end{array}$ & $\begin{array}{c}\text { Skilled } \\
\text { IV }\end{array}$ & $\begin{array}{c}\text { Unskilled } \\
\text { IV }\end{array}$ & $\begin{array}{c}\text { Skilled } \\
\text { IV }\end{array}$ & $\begin{array}{c}\text { Unskilled } \\
\text { IV }\end{array}$ \\
\hline Constant & $\begin{array}{c}1.04 \\
(2.342)\end{array}$ & $\begin{array}{l}-0.981 \\
(2.079)\end{array}$ & $\begin{array}{c}8.487 * * * \\
(2.362)\end{array}$ & $\begin{array}{c}3.801 \\
(2.375)\end{array}$ & $\begin{array}{c}3.181 \\
(2.364)\end{array}$ & $\begin{array}{c}-0.24 \\
(1.631)\end{array}$ & $\begin{array}{c}2.418 \\
(2.523)\end{array}$ & $\begin{array}{c}0.758 \\
(1.472)\end{array}$ \\
\hline Process only innovator $(d)$ & $\begin{array}{c}1.477 \\
(2.188)\end{array}$ & $\begin{array}{c}2.662 \\
(2.074)\end{array}$ & $\begin{array}{l}-1.403 \\
(1.883)\end{array}$ & $\begin{array}{l}-0.996 \\
(1.907)\end{array}$ & $\begin{array}{c}0.581 \\
(4.235)\end{array}$ & $\begin{array}{c}-1.05 \\
(2.936)\end{array}$ & $\begin{array}{c}4.118 \\
(3.820)\end{array}$ & $\begin{array}{c}-5.043 * * \\
(2.237)\end{array}$ \\
\hline $\begin{array}{l}\text { Sales growth due to new products } \\
\text { (g2) }\end{array}$ & $\begin{array}{c}1.144 * * * \\
(0.075)\end{array}$ & $\begin{array}{c}1.118^{* * *} \\
(0.070)\end{array}$ & $\begin{array}{c}0.919 * * * \\
(0.084)\end{array}$ & $\begin{array}{c}0.899 * * * \\
(0.089)\end{array}$ & $\begin{array}{c}0.872 * * * \\
(0.170)\end{array}$ & $\begin{array}{c}0.957 * * * \\
(0.118)\end{array}$ & $\begin{array}{c}1.223^{* * *} \\
(0.165)\end{array}$ & $\begin{array}{c}0.896 * * * \\
(0.096)\end{array}$ \\
\hline Located in the capital & $\begin{array}{l}-0.939 \\
(1.636)\end{array}$ & $\begin{array}{c}0.697 \\
(1.548)\end{array}$ & $\begin{array}{c}0.693 \\
(1.343)\end{array}$ & $\begin{array}{c}2.579 \\
(1.359)\end{array}$ & NA & NA & NA & NA \\
\hline Foreign owned ( $10 \%$ or more) & $\begin{array}{l}-4.657^{*} \\
(2.089)\end{array}$ & $\begin{array}{c}-8.309^{* * *} \\
(2.072)\end{array}$ & $\begin{array}{l}-2.673 \\
(1.525)\end{array}$ & $\begin{array}{l}-3.628^{*} \\
(1.609)\end{array}$ & $\begin{array}{l}13.559 \\
(9.126)\end{array}$ & $\begin{array}{l}13.559 \\
(9.171)\end{array}$ & $\begin{array}{c}6.427 \\
(6.696)\end{array}$ & $\begin{array}{c}6.427 \\
(6.718)\end{array}$ \\
\hline 2-digit industry dummies & Yes & Yes & Yes & Yes & Yes & Yes & Yes & Yes \\
\hline Time dummies & No & No & No & No & Yes & Yes & Yes & Yes \\
\hline F test, $g 2$ equation & 9.014 & 8.651 & 5.380 & 5.171 & 36.420 & 36.420 & 32.510 & 32.510 \\
\hline Pvalue & 0.000 & 0.000 & 0.000 & 0.000 & 0.000 & 0.000 & 0.000 & 0.000 \\
\hline $\begin{array}{l}\text { Sargan-Hansen } \\
\text { overidentification }\end{array} \quad$ test $\quad$ of & 4.452 & 2.436 & 3.974 & 0.612 & 6.848 & 1.408 & 6.214 & 6.799 \\
\hline Pvalue (degrees of freedom) & 0.616 & 0.876 & 0.680 & 0.996 & 0.232 & 0.923 & 0.286 & 0.236 \\
\hline Davidson-MacKinnon test of exogen & 6.449 & 5.610 & 0.156 & 0.206 & 0.200 & 0.35 & 6.160 & 0.430 \\
\hline Pvalue & 0.011 & 0.018 & 0.693 & 0.650 & 0.650 & 0.55 & 0.010 & 0.510 \\
\hline R-squared & 0.763 & 0.755 & 0.809 & 0.790 & 0.784 & 0.801 & 0.785 & 0.790 \\
\hline Number of firms & 599 & 651 & 698 & 718 & 421 & 421 & 616 & 616 \\
\hline $\begin{array}{l}\text { Source: Authors' elaboration based on } \\
\text { Notes: Product innovators are firms th } \\
\text { innovations. Product only innovators a } \\
\text { innovators. Product or process innova } \\
\text { process innovators. }\end{array}$ & $\begin{array}{l}\text { untry stud } \\
\text { have intro } \\
\text { firms that } \\
\text { s are firm }\end{array}$ & $\begin{array}{l}\text { oduct innove } \\
\text { luct innovato } \\
\text { e product inn }\end{array}$ & $\begin{array}{l}\text { Process in } \\
\text { not proces } \\
\text { s or proce }\end{array}$ & $\begin{array}{l}\text { are firms } t \\
\text { tors. Proce. } \\
\text { ators. Prod }\end{array}$ & $\begin{array}{l}\text { introduc } \\
\text { hovator: } \\
\text { ocess it }\end{array}$ & $\begin{array}{l}\text { innovatio } \\
\text { that are } p \\
\text { are firms } t\end{array}$ & $\begin{array}{l}\text { rganizatio } \\
\text { innovator: } \\
\text { both prod }\end{array}$ & $\begin{array}{l}\text { ange } \\
\text { ot product } \\
\text { lovators and }\end{array}$ \\
\hline
\end{tabular}

